\title{
Repensar a liberdade de expressĩo na Era digital: (ainda) um direito humano?'
}

\author{
Jorge dos Reis Bravo
}

Procurador da República

«Os tigres só dilaceram as suas presas para comer, enquanto nós nos temos exterminado por uma questão de parágrafos»

Voltaire, Tratado sobre a Tolerância

«A verdade deve dizer-se sempre. Sobretudo quando é inoportuna»

Miguel de Unamuno

\section{Introdução}

A primeira constatação que se pode extrair dos dados atuais sobre 0 estado da liberdade de expressão no mundo contemporâneo, é a de que atravessa «tempos difíceis». Paradoxalmente, parecem ser tempos mais difíceis ainda do que os que se viveram em contextos políitico-sociais de maiores condicionamentos explícitos daquelas liberdades. A pretexto do exercício de liberdades formalmente consagradas, estão alastrando vários

\footnotetext{
${ }^{1} 0$ presente texto serviu de suporte a uma comunicação apresentada na Conferência «A Liberdade de Expressão como Direito Humano» (assinalando os 70 anos da Declaração Universal dos Direitos Humanos e os 40 anos de Adesão à Convenção Europeia dos Direitos Humanos no âmbito do Programa «livres e Iguais 2018»), promovido pela Faculdade de Direito e Ciência Políitica da Universidade Lusófona do Porto, no dia 4 de dezembro de 2018.
} 
ULP Law Review | Revista de Direito da ULP

Vol. 13, n. .1

doi:10.46294/ulplr13n1ga3

elementos no mundo mediático que podem desvirtuar a conceção clássica e tradicional do papel dos próprios Media e dos valores assegurados por tais liberdades.

Às dificuldades por que atravessa a liberdade de expressão têm sido acrescentados óbices, materializados na tentativa de destrinça entre a «notícia falsa» (fake news) e a «verdade», o que suscita a perplexidade sobre se tal não assumirá a forma de uma «patrulha [de natureza] autoritária»; a notícia sobre a existência de trabalhos legislativos preparatórios para impedir e sancionar as fake news é uma novidade dificilmente aceitável num contexto clássico de liberdade de expressão, mas que encontra já aplicação no surgimento de plataformas e jornais online de «fact-checking», sendo, por isso, legítimo questionar se não se pretende um (novo) "policiamento da verdade".

Os Media contribuem para a estruturação do «espaço público», mas não são - nem devem ser - protagonistas do «espaço público» (são-nos os dirigentes políticos, os artistas e intelectuais, os ministros de cultos religiosos, os dirigentes desportivos, os dirigentes empresariais e sindicais, algumas dimensões da Escola, bem como de outras instituições). Os Media podem ser ainda concebidos como watchdogs da atividade pública, incluindo a políica, a empresarial, a desportiva, a mediática, a artística e a judicial.

A liberdade de expressão e de informação é a base de qualquer sistema democrático e, como refere GIOVANNI SARTORI, uma "opinião é definida como pública, não só porque é do público, mas também porque interessa à res publica, isto é, a assuntos que são de natureza pública: 0 interesse geral, 0 bem comum, os problemas colectivos ${ }^{\prime 2}$.

Após a superação de modelos administrativos de controlo prévio (censura) e sancionatório, passou a estar atribuída em exclusivo aos tribunais a função de dirimir potenciais conflitos surgidos entre 0 exerćicio da liberdade de expressão e o direito à honra e bom nome das pessoas, bem como outros direitos pessoais. Esta é uma regra de regimes políticos não autoritários e que, em maior ou menor amplitude, tutelam os valores da liberdade de expressão e de informação, concebidos igualmente como direitos fundamentais que suportam uma sociedade democrática e pluralista.

\footnotetext{
${ }^{2}$ Homo Videns: televisão e póspensamento (trad. Simonetta Neto), Terramar, Lisboa, 2000, p. 54.
} 
ULP Law Review | Revista de Direito da ULP

Vol. 13, n. .9

doi:10.46294/ulplr13n 1 ga3

Mesmo a instituiçã̃o de sistemas de regulação das atividades de comunicação social não impede que as decisões proferidas por entidades independentes possam passar, a final, pelo crivo jurisdicional em sede de recurso ${ }^{3}$. Por outro lado, também os mecanismos de auto-regulação e de natureza ético-deontológica não têm como finalidade condicionar ou limitar 0 conteúdo da informação, mas tão só conformar colegialmente 0 exercício da atividade informativa ou de opinião.

Todas estas considerações, mais ou menos consensuais, têm como pressuposto a existência de meios de comunicação social convencionais, ou seja a imprensa escrita, audiovisual ou de radiodifusão. Com a inerente identificação de elencos diretivos e dos concretos responsáveis pela produção de conteúdos e de opiniões, bem como da sua divulgação; com princípios e códigos editoriais associados, publicamente conhecidos e com relacionamentos e simpatias políitco-ideológicas também identificados.

Porém, o panorama da comunicação social tem conhecido uma acelerada e substancial modificação desde há cerca de quinze anos. São conhecidos os processos da emergência de novos agentes mediáticos em redes sociais (whatsapp e outras) plataformas, sítios e páginas virtuais pessoais, canais de televisão digital, blogs, caixas de comentários e outros veículos de divulgação de notícias e opinião na internet, com a eclosão de um paradigma mediático de "pós-verdade" e "desinformação" (fake news) que vêm pôr em causa as premissas estruturais do jornalismo convencional e colocar em perigo a sobrevivência de órgãos de informação tradicionais.

Hoje, não é mais necessário ser jornalista credenciado para divulgar factos noticiosos, verdadeiros ou falsos, ao passo que muitos periódicos clássicos estão em vias de extinção ou de transição para 0 ambiente digital. Acresce a isto a precarização dos vínculos laborais dos jornalistas, com a criação de fortes relações de dependência económica. Essas "novidades" implicam repensar todo o modelo de serviço público da comunicação social,

\footnotetext{
${ }^{3}$ Nos termos do estatuto da ERC (aprovado pela Lei n. ${ }^{0}$ 53/2005, de 08.11) constitui objetivo desta entidade administrativa independente «Assegurar a protecção dos direitos de personalidade individuais sempre que os mesmos estejam em causa no âmbito da prestação de serviços de conteúdos de comunicação social sujeitos à sua regulação» (art. 7. ${ }^{\circ}$, al. f)), e são atribuições no domínio da comunicação social «Assegurar 0 livre exerćcicio do direito à informação e à liberdade de imprensa» e «Garantir o respeito pelos direitos, liberdades e garantias» (art. 8. ${ }^{0}$, alíneas a) e d)).
} 
ULP Law Review | Revista de Direito da ULP

Vol. 13, n. .1

doi:10.46294/ulplr13n1ga3

dos operadores privados e de funcionamento do próprio jornalismo, desde a sua dimensão ética e deontológica ao seu enquadramento económico-empresarial ${ }^{4}$. A culminar esse processo de "reconfiguração" dos Media deparamos com a captura dos órgãos de informação por grupos empresariais ligados a áreas de atividade distintas e que, movidos por interesses mais ou menos explíitos, condicionam os conteúdos e as formas noticiosas e constituem-se como um restrito grupo de entidades cartelizados, mas que efetivamente determinam e orientam as agendas mediáticas, com finalidades de natureza nem sempre transparentes.

Por outro lado, das plataformas tradicionais dos Media passa-se para suportes de digitalização e desmaterialização das instâncias de produção e divulgação de conteúdos de informação e o condicionamento e manipulação da opinião pública. Todo este estado de coisas potencia atentados a valores como a honra e bom nome, 0 direito à imagem, à privacidade e à palavra, bem como cos regimes dos diversos segredos, cuja identificaçã̃o e perseguiç̄õo se tornam mais complexas, especializadas e morosas.

Neste contexto, sabendo da desterritorialização dos operadores de comunicaçôes digitais, é seguro concluir pela inadequação das formas convencionais de tutela criminal [da difamaçẫo, da devassa da vida privada, das fotografias ou gravaç̧óes ilíitas, da violação de segredos] no contexto das plataformas de difusũo digital e em rede. Importará responder a inquietantes questões, p. ex., como localizar e documentar os suportes mediáticos em causa? Quem notificar e identificar como responsável? Que legislação substantiva aplicar? De acordo com que regras processuais de produção de prova proceder? Converter os operadores de servidores de serviços digitais em fiscais ou «polícias» da informação divulgada, impondo-thes deveres de colaboração com as autoridades, e sob cominações sancionatórias (modelos de compliance mediática)? Responsabilizar e opor injunç̧oses judiciárias aos operadores de serviços de comunicaçōes electrónicas que não cooperem voluntariamente? Responsabilizar (objetivamente) as entidades que pagam 0 serviço digital que veicula os atendados aos valores referidos?

\footnotetext{
${ }^{4}$ Tendo ainda recentemente o Presidente da República chamado a atenção para a situação de «emergência» que se vive na comunicação social.
} 
ULP Law Review | Revista de Direito da ULP

Vol. 13, n. .9

doi:10.46294/ulplr13n 1 ga3

Estes problemas, que apenas incipientemente aqui se intuem, comprometem todo um conjunto de conceções que se tem como válido e assente à luz de um paradigma normativo para 0 universo da comunicaçãa social tradicional. Reclamam, por isso, outras equações e outras respostas. Algumas, julgamos que será possível extraí-las do sistema normativo jurídico-criminal e civilístico - vigente. Outras, porém, cremos que são insuscetíveis de se compatibilizar com os mecanismos jurídico-substantivos e processuais existentes, e terão de ser decantadas a partir de uma reflexão multidisciplinar.

Será, assim 0 cremos, caso de se repensar 0 enquadramento e a própria configuração da própria liberdade de expressão (e de informação) como direito humano na Era do ambiente digital.

Procuraremos, nas linhas que se seguem, decantar alguns contributos para esse debate.

\section{Liberdade de expressão e liberdade de informação}

A liberdade de expressão e de informação, enquanto direito fundamental, encontra-se consagrada em instrumentos internacionais de referência inquestionável, bem como na nossa Constituição; assim, encontramo-lo previsto no art. 19. ${ }^{\circ}$ da DUDH ${ }^{5}$, no art. $10 .{ }^{\circ} \mathrm{da}$ $\mathrm{CEDH}^{6}$, no art. 11. ${ }^{0}$, n. ${ }^{0} 1$ da CDFUE, bem como no art. 37. ${ }^{\circ}$, n. ${ }^{0} 1$ da CRP ${ }^{8}$.

\footnotetext{
${ }^{5}$ Cujo teor é o seguinte: Artigo 19. «Todo o indivíduo tem direito à liberdade de opinião e de expressão, o que implica o direito de não ser inquietado pelas suas opiniões e 0 de procurar, receber e difundir, sem consideração de fronteiras, informações e ideias por qualquer meio de expressão».

${ }^{6}$ Cujo teor é o seguinte: Artigo 10. (Liberdade de expressão) «1. Qualquer pessoa tem direito à liberdade de expressão. Este direito compreende a liberdade de opinião e a liberdade de receber ou de transmitir informaçóes ou ideias sem que possa haver ingerência de quaisquer autoridades públicas e sem considerações de fronteiras. 0 presente artigo não impede que os Estados submetam as empresas de radiodifusão, de cinematografia ou de televisão a um regime de autorização prévia. 2. 0 exercício desta liberdades, porquanto implica deveres e responsabilidades, pode ser submetido a certas formalidades, condiçōes, restriç̧ōes ou sançōes, previstas pela lei, que constituam providênncias necessárias, numa sociedade democrática, para a segurança nacional, a integridade territorial ou a segurança pública, a defesa da ordem e a prevenção do crime, a protecção da saúde ou da moral, a protecção da honra ou dos direitos de outrem, para impedir a divulgação de informaççes confidenciais, ou para garantir a autoridade e a imparcialidade do poder judicial»s.
} 
ULP Law Review | Revista de Direito da ULP

Vol. 13, n. .9

doi:10.46294/ulplr13n 1 ga3

0 art. 37. ${ }^{\circ}$ da CRP encerra dois feixes de direitos distintos: a liberdade de expressão e a liberdade de informação, dotando os seus titulares de uma posição jurídica complexa. Seguidamente, tentaremos distingui-los, de acordo com uma formulaçãa consensual na doutrina.

A liberdade de expressão compreende (i) o direito negativo a não se ser impedido de exprimir e divulgar 0 pensamento, ideias, opiniões, factos, conhecimentos, mensagens publicitárias, criações artísticas, de todo o tipo e por qualquer meio, e (ii) na sua dimensão positiva, uma pretensão de acesso aos meios de expressão, bem como (iii) uma pretensão de acesso, nos termos da lei, às estruturas de serviço público de rádio e de televisão.

A liberdade de informação, por seu turno, engloba (i) 0 "direito de informar", (ii) 0 "direito de se informar" e (iii) o "direito de ser informado". 0 primeiro desdobra-se num direito análogo ao direito negativo da liberdade de expressão, com a diferença de que este tem por objeto "informações". Por seu turno, o "direito de se informar" corresponde à prerrogativa de busca de fontes de informação e de recolha de informação, ao passo que 0 "direito de ser informado" consiste no direito (positivo) de ser objetiva e adequadamente informado pelos Media e pelos poderes públicos.

Adiante veremos melhor como se deve enquadrar e interpretar a regra consagrada no art. 10. ${ }^{\circ}$ da CEDH relativamente ao conteúdo da liberdade de expressão (e de informação) bem como as suas ressalvas ou exceções.

As relações entre os direitos fundamentais e os direitos humanos centram-se, como é sabido, em torno da natureza constitucionalizada dos primeiros e da aptidão

\footnotetext{
${ }^{7}$ Cujo teor é 0 seguinte: Artigo 11. (Liberdade de expressão e de informação) «l. Todas as pessoas têm direito à liberdade de expressão. Este direito compreende a liberdade de opinião e a liberdade de receber e de transmitir informações ou ideias, sem que possa haver ingerência de quaisquer poderes públicos e sem consideração de fronteiras».

${ }^{8}$ Cujo teor é 0 seguinte: «Artigo 37. (Liberdade de expressão e informação): 1. Todos têm 0 direito de exprimir e divulgar livremente 0 seu pensamento pela palavra, pela imagem ou por qualquer outro meio, bem como 0 direito de informar, de se informar e de ser informados, sem impedimentos nem discriminações» (com as alterações do art. 29. ${ }^{\circ}$ da Lei Constitucional n. ${ }^{0}$ 1/82, D.R. n. ${ }^{0}$ 227/1982, Série I, de 1982-09-30, em vigor a partir de 30.10.1982 e do art. 20. ${ }^{\circ}$ da Lei Constitucional n. ${ }^{0}$ 1/97, D.R. n. ${ }^{0}$ 218/1997, Série I-A, de 1997-09-20, em vigor a partir de 05.10.1997).
} 
ULP Law Review | Revista de Direito da ULP

Vol. 13, n. .9

doi:10.46294/ulplr13n1ga3

tendencialmente internacional ou universalizante dos segundos? comungando de múltiplos aspetos no tocante à configuração do seu conteúdo material, quer no tocante à sede da sua titularidade (a pessoa humana) e à sua oponibilidade (ao Estado, organizações e outros indivíduos).

Por isso, a liberdade de expressão assume presença nos dois níveis de proteção, podendo falar numa tutela multinível, enquanto direito humano e direito fundamental, consagrado em mais do que um instrumento; esta circunstância não deverá ser nunca esquecida quando esteja em causa a ponderação da solução de um conflito entre esse direito humano - que é também um direito fundamental - e outros que potencial ou efetivamente possam com ele colidir. Por outro lado, a Carta dos Direitos Fundamentais da União Europeia tornou-se juridicamente vinculativa com a entrada em vigor do Tratado de Lisboa $^{10}$, ao mesmo tempo que se processou a adesão e confirmação dos direitos fundamentais garantidos pela Convenção Europeia para a Proteção dos Direitos do Homem e das Liberdades Fundamentais ${ }^{11}$ e resultantes das tradições constitucionais comuns aos Estados-Membros.

A incorporação no Tratado de Lisboa do conteúdo das liberdades e direitos consagrados e princípios da CDFUE e da CEDH implica que se reconheça o acquis do TEDH, exprimindo a natureza indissociável das duas categorias de direitos, que enformam, ou devem enformar, os ordenamentos jurídicos dos Estados-Membros da União Europeia.

\footnotetext{
${ }^{9}$ Tendo recentemente sido questionada a intransigente validade universal da DUDH, face a conceçõos relativistas, propondo-se uma reformulação do conteúdo do seu catálogo, tendo em atenç̧ão características e peculiaridades de natureza regionalista ou nacionalista.

${ }^{10} \mathrm{Cfr}$. art. $6 .{ }^{0}$, n. ${ }^{\circ} 1$ «A União reconhece os direitos, as liberdades e os princípios enunciados na Carta dos Diretios Fundamentais da União Europeia, de 7 de Dezembro de 2000, com as adaptaçōes que lhe foram introduzidas em 12 de Dezembro de 2007, em Estrasburgo, e que tem o mesmo valor jurídico que os Tratadoss.

"Cfr. art. 6. ' , n.s 2 e 3: «2. A União adere à Convenção Europeia para a Protecç̃ó dos Direitos do Homem e das Liberdades Fundamentais. Essa adesão não altera as competências da União, tal como definidas nos Tratados.

3. Do direito da União fazem parte, enquanto princípios gerais, os direitos fundamentais tal como os garante a Convenção Europeia para a Protecção dos Direitos do Homem e das Liberdades Fundamentais e tal como resultam das tradiçoes constitucionais comuns aos Estados-Membros.»
} 
ULP Law Review | Revista de Direito da ULP

Vol. 13, n. .9

doi:10.46294/ulplr13n 1 ga3

É salvaguardado 0 «direito ao silêncio», enquanto direito negativo, i.e., 0 direito a não comunicar pensamentos ou informações e 0 direito a não ser informado, como corolário da liberdade negativa de pensamento.

0 art. $37 .{ }^{\circ}$, n. ${ }^{3} 3$ da CRP, por seu turno, proíbe a censura, consubstanciando um direito negativo (a não ser impedido de exprimir o pensamento, ideias e opiniões), mas exigindo também do Estado uma atuação positiva perante atendados de particulares que, por força do art. $18 .{ }^{\circ}, n^{0} 1$ da CRP, estão vinculados a respeitar este direito fundamental. 0 direito de resposta e de retificacãa, consagrado no art. $37 .{ }^{\circ}$, n. ${ }^{0} 4$ da CRP, melhor concretizado no art. $2 .{ }^{0}$, n. ${ }^{0}$ 2, alíneas c) e f) da Lei n. ${ }^{0}$ 2/99, de 13.01 (Lei de Imprensa), atribui aos sujeitos afetados por um certo facto ou opinião que entendam ser ofensivo, inverídico ou inexato um direito potestativo para aduzirem contraditório. A sua funcionalidade visa, essencialmente: (i) permitir a defesa dos direitos de personalidade de quem se sinta afetado por uma determinada comunicação e (ii) funcionar como garante do pluralismo de ideias e da descoberta da verdade, facultando ao público o acesso a pontos de vista diferentes ou contraditórios.

0 âmbito subjetivo abrange tanto as pessoas singulares como as pessoas coletivas ${ }^{12}$, podendo estas produzir e exteriorizar posições próprias e difundir informações, em termos assimiláveis, nos termos do art. 12. ${ }^{\circ}$, n. ${ }^{0} 2$ da CRP.

Quanto aos indivíduos, não é exigida a maioridade, mas apenas um mínimo de capacidade natural. Enquanto direito humano e universal é reconhecido tanto a cidadãos nacionais como a estrangeiros e apátridas.

De entre os vários direitos especiais ou qualificações que a liberdade de expressão e de informação, avulta a liberdade de imprensa. 0 direito a informar dos jornalistas tem,

\footnotetext{
${ }^{12}$ De acordo com RENATO MLLITÃO, «Por princípio, as entidades coletivas privadas gozam do direito à honra objetiva ou exterior. Porém, não gozam do direito à honra subjetiva ou interior, o qual é inseparável do indivíduo. Já as entidades coletivas públicas somente poderão gozar do direito à honra objetiva ou exterior se possuírem um certo grau de autonomia e representarem de algum modo um contra poder face ao Estado. Grosso modo, a honra pode ser agredida quer através da formulação de jứzos de valor, quer pela imputação de factos. Todavia, em abstrato, a formulacãa de um juízo de valor envolve um potencial lesivo da honra manifestamente inferior ao que compreende a imputação de um facto. Também por isso, em caso de dúvida, deve considerar-se que se está perante um júizo valorativo.», Julgar online, março 2016, p. 40.
} 
ULP Law Review | Revista de Direito da ULP

Vol. 13, n. .9

doi: 10.46294/ulplr13n1 ga3

porém, como contrapartida um dever de informar com verdade e objetividade, como consequência da «missão de serviço publico» que lhes compete, impondo-se-thes um dever de contraditório, procurando accutelar as posiçōes de todos os afetados pela divulgação de elementos informativos que podem entrar em colisão com o direito à honra e ao bom nome.

\section{Conceito constitucional de "informaçãa" e a distinçãa entre "factos" e "opiniōes"}

A distinção entre factos e opiniões assume particular relevância - pelas suas implicaçães - no confronto da liberdade de expressão e de informação com outros direitos fundamentais, como é o caso do direito à honra e ao bom nome, nomeadamente no que respeita ao ónus da prova quanto à veracidade de factos. Desde logo, a distinção entre factos e opiniões é nuclear no que respeita à exigência da observação do dever deontológico dos meios de comunicação social em separar, na informação que fornecem, os factos ou notícias das opiniões, comentários ou crónicas.

De uma forma tendencialmente simplificadora, por informação pode entender-se 0 conjunto de dados e conhecimentos que contribuem para 0 esclarecimento e formação do ser humano, quer o consideremos como um ser individual, abrangendo os seus interesses individuais, quer o tomemos na sua dimensão social, abarcando interesses públicos ou da coletividade. Ou seja, o conceito normativo-constitucional de informação deve ser entendido em sentido lato abarcando todo o tipo de dados e conhecimentos que satisfaçam os bens jurídicos tutelados pela liberdade de expressão e de informação.

A delimitação que a este respeito se afigura viável estabelecer, em termos muito esquemáticos e preliminares, é a da contraposição entre factos e ideias/opiniões. Enquanto um facto é uma proposição dirigida a existência exterior de um certo dado, sendo por isso sensorial ou racionalmente demonstrável, iá uma ideia ou opinião é uma 
ULP Law Review | Revista de Direito da ULP

Vol. 13, n. .1

doi:10.46294/ulplr13n1ga3

proposição que encerra juízos de valor ou de apreciação relativamente a factos ou a outras ideias ou opiniões, pelo que a sua veracidade não pode ser, por natureza, comprovada.

Esse critério de delimitação entre factos e opiniões não é consensual. Existem diversos âmbitos discursivos com acentuada ambiguidade, como as peças que encerram interrogacọoes, "perguntas de retórica", citaç̧óes, sugestỗes, relacionamentos e insinuaçōes. Por um lado, estes tipos de discurso partilham com as opiniões a característica de não poderem ser classificadas como verdadeiros ou falsos. Por outro, afastam-se das meras opiniōes ou juízos valorativos, por pressuporem e/ou afirmarem factos. Tais zonas compósitas deverão ser classificadas, designadamente para efeitos de exigência da prova da sua verdade, segundo a doutrina, de acordo com o critério do elemento preponderante da imputaçaco,o, procurando atender (i) ao contexto em que o discurso foi proferido, (ii) à interpretação que o homem médio dele possa fazer e (iii) à efetiva possibilidade de prova da veracidade desses factos.

Convém, portanto, reconhecer que nem sempre se torna um exercício fácil estabelecer uma clara delimitaçã̃o entre informação e opinião, uma vez que peças ou artigos de opinião podem conter parcialmente conteúdos que não sejam de mera opiniã̃o, do mesmo passo que nem tudo o que consta de uma peça ou artigo informativo é estritamente factual.

\subsection{Limites à liberdade de expressão e de informaç̃̃o?}

Se se analisar detalhadamente a conceção sobre liberdade de expressão nos EUA e no sistema do CdE, através da jurisprudência do TEDH, verificam-se diferenças assinaláveis: ali, sobretudo com base na Primeira Emenda à Constituiç̧ão e da jurisprudência do Supremo Tribunal Federal (dotado de poderes de fiscalização da constitucionalidade), admite-se 0 exerćício da liberdade de expressão com muita amplitude, sendo os respetivos limites muito contados. Em princípio, as restrições à liberdade de expressão não podem ser determinadas pelo conteúdo das expressões concretamente em causa. No caso New York 
ULP Law Review | Revista de Direito da ULP

Vol. 13, n. .1

doi:10.46294/ulplr13n 1 ga3

Times Co vs. Sullivan ${ }^{13}$, o Supremo definiu que as críticas a servidores públicos (public officials) só poderiam dar origem a indemnizaçôes se os textos em causa fossem publicados com consciência da falsidade (actual malice) ou com total desprezo pela verdade (reckless disregard of the truth). Num conjunto de outras decisões em leading cases, o Supremo Tribunal dos EUA assentou na consideração da redução da tutela da honra e bom nome de figuras públicas, com base na Primeira Emenda, por tais pessoas se terem de sujeitar a um escrutínio mais exigente por parte da opiniã̃o pública e da comunicação social, obrigando a um acesso mais amplo sobre a vida pública e mesmo aspetos da vida privada dessas figuras, e a aceitar críticas mais impiedosas, contundentes, deselegantes ou sarcásticas (v.g. casos Hustler Magazine vs. Falwell, Texas vs. Johnson).

A interpretação jurisdicional da Primeira Emenda tem levado a que a conceção da liberdade de expressão nos EUA conheça uma amplitude que não tem paralelo na Europa, admitindo a legitimidade de discursos violentos, ofensivos, racistas, anti-semitas e antireligiosos, desde que não instiguem (de forma direta) a violência propriamente dita ou se reconduzam a discursos de ódio.

A configuração normativa e jurisprudencial do sistema da CEDH e do TEDH não tem correspondência com essa interpretação da liberdade de expressão, muito menos com a amplitude reconhecida nos EUA, conforme abaixo se verá melhor e resulta, desde logo, do $\S 2 .^{\circ}$ do art. 10. ${ }^{\circ}$ da CEDH. Não tendo a dimensão (quase) intocável que assume no tratamento jurisprudencial norte-americano, constitui também uma liberdade fundamental, não só com relevo individual mas também estrutural em termos sociais, só podendo ser restringida com razões especialmente ponderosas ${ }^{14}$.

Os valores do bom nome e da honra e 0 valor da liberdade de expressão e de informação colocam inevitavelmente em conflito dimensões positivas individuais. A liberdade de expressão e 0 direito de crítica assumem espessura de natureza social. Todavia, seria imprudente concluir que o valor da honra e do bom nome assume relevo

\footnotetext{
${ }^{13}$ No processo estava em causa a queixa de um chefe da políia que se sentira injuriado por o jornal ter noticiado factos não exatamente rigorosos quanto à atuaç̧ão da polícia relativamente a atividades da organização de Martin Luther King, Jr).

${ }^{14} \mathrm{Cfr}$. FRANCISO TeIXEIRA DA MOTA, A Liberdade de Express̃̃o em Tribunal, Lisboa, FFMS, 2013, p. 51.
} 
ULP Law Review | Revista de Direito da ULP

Vol. 13, n. .9

doi:10.46294/ulplr13n1ga3

exclusivamente individual. É certo que a sua matriz se encontra no indivíduo ou na pessoa, mas 0 Estado democrático pretende que tais valores sejam tutelados não apenas por assumirem densidade individual mas por thes reconhecer uma refração social ou comunitária.

Não é, por isso, rigoroso afirmar-se que no confronto entre liberdade de expressão e direito à honra e ao bom nome, há um conflito entre valores sociais, de um lado e valores individuais, de outro. A linha de demarcação é fluida e ambígua ${ }^{15}$, pouco nítida e com uma geometria variável.

Apesar da inadmissibilidade consitiucional de formas de censura, como se viu, tal não significa que não possa haver limites à liberdade de expressão e de informaç̃õ. Podem identificar-se três tipos de limites: (i) limites imediatos ou imanentes; (ii) limites por restriçōes legislativas, e (iii) limites emergentes de colisão de direitos ${ }^{16}$.

Constituririam "limites imanentes implícitos" 0 conteúdo essencial dos demais direitos fundamentais, os "valores comunitários básicos" e "os princípios fundamentais da ordem constitucional" em que pontifica o principio da dignidade da pessoa humana, excluindo-se, por isso, do âmbito normativo do direito à liberdade de expressão a possibilidade de injuriar através de afirmações falsas.

Porém, esta conceção da teoria dos limites imanentes implíritos encontra vários escolhos na teoria consitiucional ${ }^{17}$. Acolhendo essas objeções e perfilhando a teoria externa das restriç̄óes aos direitos fundamentais, a liberdade de expressão apresentar-se-ia como um direito tendencialmente sem restriç̄es ao qual, todavia, se adscrevem limitações

\footnotetext{
${ }^{15}$ Como refere FARIA COSTA, «(...) na protecção da honra ou do bom nome vai também implíita uma dimensão de tonalidade colectiva» recuperando o conceito de «porosidade dos confins»», de Salvatore Veca, em La penultima parola e altri enigmi [ «Tribunal Europeu dos Direitos Humanos [caso Lopes Gomes da Silva c. Portugal - queixa n. 37 698/97], acórdão de 28 de Setembro de 2000 - A informação, a honra, a crítica e a pós-modernidade (ou os equilibrios instáveis do nosso desassossego)», Revista Portuguesa de Ciência Criminal, Ano 11, Fasc 1. ${ }^{0}$ - jan.-mar. 2001, p. 151].

${ }^{16}$ Assim, JOÃO TORNADA, «Liberdade de expressão ou "liberdade de ofender"? - 0 conflito entre a liberdade de expressão e de informação e o direito à honra e ao bom nome», 0 Direito, N. ${ }^{0}$ 150, 2018, pp. 130 ss.

${ }_{17}$ Cfr. JORGE REIS NOVAIS, Direitos Fundamentais e Justica Constitucional em Estado de Direito Democrático, Coimbra Editora, 2012, p. 82. Contra, também JOÃO TORNADA, «liberdade de express̃̃o ou "liberdade de ofender"? - 0 conflito entre a liberdade de expressão e de informação e o direito à honra e ao bom nome», loc. cit., p. 136.
} 
ULP Law Review | Revista de Direito da ULP

Vol. 13, n. .9

doi:10.46294/ulplr13n1ga3

externas decorrentes da necessidade da sua harmonização com os demais direitos fundamentais e interesses constitucionalmente protegidos.

Assim, considerando isoladamente os limites imediatos, 0 alcance da liberdade de expressão e de informação é tão amplo quanto a criatividade e imaginação dos seus titulares, abarcando todo o tipo de informações, tanto factos como opiniões, mesmo as mais ininteligíveis, falsas ou contundentes. Apenas não serão tuteladas os pensamentos ou as informaç̃oes que configurem plágio (i.e, juridicamente pertences a terceiros).

Os limites à liberdade de expressões por meio de restriç̃óes legislativas são definidos pelo legislador ordinário no sentido de que a restrição da liberdade de expressão prossiga sempre um interesse constitucionalmente tutelado e se circunscreva ao estritamente necessário, não se ignorando as objeções à legitimidade constitucional da incriminação da ofensa a organismo, serviço ou pessoa coletiva (art. 187. ${ }^{\circ}$ do (P), de ultraje de símbolos estrangeiros (art. 323. ${ }^{\circ}$ do (P) ou do ultraje de símbolos nacionais e regionais (art. 332. ${ }^{\circ}$ do $(P)$.

Porém, serão já, inequivocamente, exemplos de leis restritivas a incriminação da violação de certos bens jurídicos, como os tipos de crime contra a honra - a injúria, a difamação e a calúnia (artigos 180. ${ }^{\circ}, 181 . .^{\circ}$ e 183. ${ }^{\circ}$ do (P) -, de fotografias e gravações ilícitas (art. 199. o do (P), de instigação pública a um crime (art. 297. . do (P), de violaçã̃o de segredo de justiça (art. 371. ${ }^{0}$ do (P), de violação de segredo por funcionário (art. 383. ${ }^{\circ}$ do (P) e de violação de segredo de Estado (art. 316. ${ }^{0}$ do (P). Também se pode identificar outro limite legalmente previsto na incriminação por desobediência (simples) dos comportamentos previstos no n. ${ }^{0} 2$ do art. $88 .{ }^{\circ}$ do $\mathrm{CPP}^{18}$.

\footnotetext{
${ }^{18}$ É 0 seguinte 0 teor da norma: «2. Não é, porém, autorizada, sob pena de desobediência simples:

a) A reprodução de peças processuais ou de documentos incorporados no processo, até à sentença de 1. ${ }^{a}$ instância, salvo se tiverem sido obtidos mediante certidão solicitada com menção do fim a que se destina, ou se para tal tiver havido autorização expressa da autoridade judiciária que presidir à fase do processo no momento da publicação;

b) A transmissão ou registo de imagens ou tomadas de som relativas à prática de qualquer acto processual, nomeadamente da audiência, salvo se a autoridade judiciária referida na alínea anterior, por despacho, a autorizar; não pode, porém, ser autorizada a transmissão ou registo de imagens ou tomada de som relativas a pessoa que a tal se opuser;

c) A publicação, por qualquer meio, da identidade de vítimas de crimes de tráfico de pessoas, contra a liberdade e autodeterminação sexual, a honra ou a reserva da vida privada, excepto se a vítima consentir
} 
ULP Law Review | Revista de Direito da ULP

Vol. 13, n. .9

doi:10.46294/ulplr13n 1 ga3

Assumindo-se também a liberdade de imprensa (escrita) como uma das manifestações da liberdade de expressão e de informação, o legislador consagra expressamente a proibição da censura (art. 1. ${ }^{0},{ }^{0}{ }^{0} 3$ da Lei de Imprensa) e, simetricamente, os «únicos limites» que aquela liberdade pode comportar no art. $3 .^{0}$ do mesmo diploma: «(...) os que decorrem da Constituição e da lei, de forma a salvaguardar o rigor e a objectividade da informação, a garantir os direitos ao bom nome, à reserva da intimidade da vida privada, à imagem e à palavra dos cidadãos e a defender 0 interesse público e a ordem democrática». Esta formulação pressupõe que os limites à liberdade de imprensa decorram da necessidade de tutela constitucional - ou legal - de valores ou direitos colidentes com tal liberdade.

Por seu turno, na Lei n. ${ }^{0}$ 27/2007, de 30.07 (Lei da Televisão e dos serviços audiovisuais a pedido), além de outras restrições de programação, nomeadamente discursos de ódio e discriminação e conteúdos pornográficos ou violentos, prevêem-se no seu art. 27. ${ }^{0}$, n. ${ }^{0} 1$, como limites à liberdade de programação: «(...) a dignidade da pessoa humana e os direitos, liberdades e garantias fundamentais».

Por fim, a Lei n. ${ }^{0}$ 54/2010, de 24.12 (Lei da Rádio), no seu art. $30 .{ }^{\circ}$, n. ${ }^{0} 1$, consagra como limites à liberdade de programação «(...) a dignidade da pessoa humana e os direitos, liberdades e garantias fundamentais», para além de 0 n. ${ }^{0} 2$ estatuir a proibição de conteúdos de programação que possam «(...) incitar ao ódio racial, religioso, políitico ou gerado pela cor, origem étnica ou nacional, pelo sexo, pela orientação sexual ou pela deficiência».

Podendo aceitar-se que não existe uma hierarquizaçãa pré-definida entre os vários direitos fundamentais ${ }^{19}$, a aferição dos seus limites por via interpretativa deve obedecer a

expressamente na revelação da sua identidade ou se 0 crime for praticado através de órgão de comunicação social.

3. Até à decisão sobre a publicidade da audiência não é ainda autorizada, sob pena de desobediência simples, a narração de actos processuais anteriores àquela quando o juiz, oficiosamente ou a requerimento, a tiver proibido com fundamento nos factos ou circunstâncias referidos no n. ${ }^{0} 2$ do artigo anterior. 4. Não é permitida, sob pena de desobediência simples, a publicação, por qualquer meio, de conversações ou comunicações interceptadas no âmbito um processo, salvo se não estiverem sujeitas a segredo de justiça e os intervenientes expressamente consentirem na publicação».

${ }^{19}$ Posição que, como se sabe, não é pacífica ou consensual, designadamente no tocante à aceitação por alguma doutrina constitucional de uma grelha axiológico-valorativa em que pontifica o direito à vida -sendo 
ULP Law Review | Revista de Direito da ULP

Vol. 13, n. .1

doi:10.46294/ulplr13n 1 ga3

jứzos de ponderação de bens, de maximização e de proporcionalidade, de forma a garantir uma relação de coexistência equilibrada e harmoniosa, quando entre dois ou mais diretos se estabeleça conflito, conforme se verá infrá ${ }^{20}$.

\subsection{0 direito à honra e ao bom nome e outros direitos (direito à privacidade, à imagem, à palavra, à presunção de inocência, aos segredos profissionais e de investigação)}

0 direito fundamental ao bom nome e à reputaçãa encontra-se consagrado no artigo 26. ${ }^{\circ}$ n. ${ }^{0} 1$ da CRP e ainda no artigo 12. ${ }^{\circ}$ da DUDH, parte integrante da Lei Fundamental (art. 16. ${ }^{\circ}$, n. ${ }^{0} 2$ da (RP). Ao nível da lei ordinária, é tutelado como atributo do direito de personalidade no art. $70{ }^{\circ}$ do CC (fazendo parte do núcleo de valores da integridade moral da pessoa).

Com efeito, o conceito de honra, entre nós, assume uma "dupla conceção fácticonormativa" abarcando tanto a honra objetiva/externa como a honra subjetiva/interior e decorre diretamente da dignidade da pessoa humana.

Assim, o bom nome (ou reputação ou honra objetiva/externa) reporta-se ao prestígio e a consideração social que um determinado sujeito goza no meio onde se move. Por seu turno, a honra subjetiva/interna abarca o conjunto mínimo de valores éticos e morais, que são razoavelmente consideradas essenciais, para que um indivíduo possa nutrir estima e consideração por si próprio. Este direito fundamental não se esgota na proteção pessoal e moral da honra e do bom nome, pois engloba também o direito ao crédito pessoal.

0 direito à honra e ao bom nome não protege indistintamente os seus titulares de toda e qualquer ofensa, porquanto o direito não pode intervir sempre que a linguagem utilizada incomoda ou fere suscetibilidades pessoais do visado. 0 âmbito normativo do direito à honra e ao bom nome há-de reportar-se a um feixe nuclear de qualidades éticas e

também concebido como um direito não absoluto (v.g. a legíitima defesa, a guerra) - e em que o princípio jurisgénico referencial da dignidade humana - que não é em si um direito fundamental - é aceite como único valor jusfundamental insuscetível de restrições.

${ }^{20} \mathrm{Em} 3.2$. 
ULP Law Review | Revista de Direito da ULP

Vol. 13, n. .9

doi:10.46294/ulplr13n1ga3

morais que devem existir para que a pessoa tenha apreço por si própria e não se sinta desprezada pelos outros, tidas como essenciais a luz da conceção social dominante, i.e., "segundo a sã opinião da generalidade das pessoas de bem"21. Pode encontrar-se aí 0 limite imediato ou imanente deste direito fundamental.

Todavia, o Tribunal Constitucional, embora se tenha pronunciado escassamente sobre a matéria em causa, já por duas vezes emitiu o entendimento de que a tutela da honra e do bom nome das "figuras publicas" é a priori menor do aquela de que gozam os cidadãos comuns, pois seria «possivel que, mesmo antes de um raciocínio que conduza à tentativa de harmonização dos direitos "em conflito" [...] se tenha de concluir que um desses direitos - in casu o denominado direito à honra - tenha uma esfera de proteção algo diminuída à partida» ${ }^{22}$.

Tal equivale a considerar que, previamente a qualquer "colisão de direitos", emerge logo, enquanto limite imanente implícito do direito à honra e ao bom nome, uma menor amplitude da tutela que estes sujeitos gozam, em face da conveniência e necessidade de escrutínio público dos seus atos.

Para quem rejeite a teoria dos limites imanentes implíicitos, há-de entender que estas formulações só são possíveis no momento em que se instala a colisão de direitos fundamentais. Até esse momento, o âmbito normativo do direito a honra e ao bom nome não deve variar de acordo com 0 tipo de poder ou a notoriedade que o seu titular reveste. Apenas no confronto com a liberdade de expressão e de informação que surgiria a necessidade de, «(...) no caso concreto, o direito a honra e ao bom nome ceder perante 0 interesse (publico) na discussão de certos assuntos»» ${ }^{23}$.

Também relativamente aos demais direitos pessoais (de personalidade) incluídos no âmbito do art. 26. ${ }^{0},{ }^{0}{ }^{0} 1$ da CRP - «ao desenvolvimento da personalidade, à capacidade civil, à cidadania, (...), à imagem, à palavra, à reserva da intimidade da vida privada $e$

\footnotetext{
${ }^{21}$ BELEZA DOS SANTOS, «Algumas considerações jurídicas sobre crimes de difamação e injúria», RLJ, Ano 92, n. ${ }^{0} 3152$, p. 168.

${ }^{22}$ Acs. TC n. ${ }^{0 s} 113 / 97$, de 05.02.1997 e 292/2008 de 29.05.2008.

${ }^{23}$ JOÃO TORNADA, «Liberdade de expressão ou "liberdade de ofender"? - 0 conflito entre a liberdade de expressão e de informaçãa e o direito à honra e ao bom nome», loc. cit., p. 136.
} 
ULP Law Review | Revista de Direito da ULP

Vol. 13, n. .9

doi:10.46294/ulplr13n 1 ga3

familiar e à protecção legal contra quaisquer formas de discriminação» - é possível estabelecer soluções para dirimir potenciais conflitos com a liberdade de expressão e de informação.

\section{A CEDH e a vinculação dos tribunais nacionais à jurisprudência do TEDH}

0 ordenamento jurídico nacional contemporâneo incorpora regimes normativos de instrumentos internacionais e europeus, que integram de pleno 0 sistema normativo vigente. É 0 caso paradigmático da CEDH, instrumento normativo que vincula o Estado português na ordem jurídica interna e na ordem jurídica internacional; plenamente vigente em Portugal (e em mais 46 países), com valor supralegal (mas infraconstitucional), a CEDH vincula o intérprete e aplicador da lei nacional no tocante à conformação de soluções que contendem com os direitos humanos, segundo os seus cânones e orientações.

A CEDH vigora na ordem jurídica portuguesa desde $1978^{24}$ e goza de força supralegal, prevalecendo sobre as leis ordinárias, por força do art. $8 .{ }^{0}$, n. ${ }^{0} 2$ da CRP. Por esta razão, as instâncias judiciais internas dos Estados Contratantes são a "primeira instância" ${ }^{25}$ de aplicação da CEDH, como decorre do seu art. 13. ${ }^{\circ}$. Por seu turno, 0 art. $35 .^{\circ}$ da CEDH dispõe que só uma vez esgotadas todas as vias de recurso internas, poderá o Tribunal de Estrasburgo intervir.

Nessa medida, o TEDH, enquanto órgão jurisdicional inserido no sistema de fiscalização da conformidade dos ordenamentos jurídicos nacionais com o quadro jurídico internacional de direitos humanos do Conselho da Europa, veicula correntes de interpretação "autêntica" relativamente à conformidade das decisões de autoridades

\footnotetext{
${ }^{24}$ Portugal assinou a Convenção e os Protocolos n. ${ }^{\circ}$ 1, 3 e 5 em 22.11.1976 e o Protocolo n. ${ }^{0}$ 2, em 27.01.1977. Porém, só através da Lei n. ${ }^{0} 65 / 78$, de 13.10 a Convenção e os seus cinco primeiros Protocolos foram aprovados.

${ }^{25} \mathrm{~A}$ expressão é descomprometida, tendo de ser encarada com reserva, dado que o TEDH não funciona como tribunal de recurso, não procedendo à cassação de decisões judiciais internas. Pode, no entanto, em decorrência de uma decisão daquele tribunal, haver fundamento para a legitimar a interposição de um recurso de revisão, quer no âmbito penal quer no plano civil (cfr. artigos 449. ${ }^{\circ}$, n. ${ }^{\circ}$ l, al. g) do (PP e 696. ${ }^{\circ}$, a. f) do (PC).
} 
ULP Law Review | Revista de Direito da ULP

Vol. 13, n. .9

doi:10.46294/ulplr13n1ga3

nacionais segundo o texto da CEDH, sobre diversas matérias, entre as quais a liberdade de expressão (art. 10. ${ }^{\circ} \mathrm{da}$ CEDH) ${ }^{26}$.

Da previsão do direito à liberdade de expressão, tal como é consagrado na Convenção, decorrem para os Estados contratantes e a ela vinculados obrigações (positivas) de criarem condições para que possa haver lugar à livre emissão e circulação das opiniões, ideias e informação; reflexamente, impõe-se aos Estados a obrigação de abstenção de ingerências no exerć́cio desse direito, salvo nos casos e nas condições permitidas pelo n. ${ }^{0} 2$ da norma.

A CEDH coloca ao intérprete e aplicador desafios que emergem da própria técnica legislativa adotada no artigo 10. (e noutros artigos da Convenção sobre liberdades), estabelecendo 0 n. ${ }^{0} 1$ a garantia a uma ampla liberdade de opinião, de receber e transmitir informações e ideias, sem ingerência das autoridades; 0 n. ${ }^{0} 2$ prevê as hipóteses em que essa ingerência pode ocorrer, através de diversas restrições e mesmo sanções, desde que previstas na lei, fundadas em finalidades legítimas e consideradas necessárias numa sociedade democrática.

Tais finalidades, estabelecidas no n. ${ }^{0} 2$, podem ser, quer de interesse geral (garantir a segurança e a defesa nacional; a ordem e a prevenção criminal; a proteção da saúde e da moral), quer ordenadas à proteção de interesses individuais (o bom nome e reputação, os direitos de outrem); podem ainda ter como finalidade impedir a divulgação de informações confidenciais ou a proteger a autoridade e a imparcialidade do poder judicial.

0 conceito de ingerência das autoridades assume decisiva importância na economia da jurisprudência do TEDH, que aprecia, casuisticamente, a legitimidade e necessidade da ingerência, numa sequência metodológica que compreende dois momentos: em primeiro lugar, a indagação sobre se a medida adotada pelas autoridades (as mais das vezes, a decisão interna definitiva que condenou na esfera penal ou civil 0 autor da opinião ou informação) estava prevista no ordenamento jurídico interno, de modo acessível e previsível; em segundo lugar, a indagação sobre se essa medida visou a prossecução de

${ }^{26}$ Sobre a questão, reportada aos casos nacionais apreciados naquela instância, RAQUEL S. PIRES ANTUNES CRUZ, A jurisprudência do artigo 10. da Convencão Europeia dos Direitos do Homem nos casos portugueses, Dissertação de Mestrado apresentada à Faculdade de Direito da Universidade de Coimbra, 2016. 
ULP Law Review | Revista de Direito da ULP

Vol. 13, n. .9

doi:10.46294/ulplr13n 1 ga3

algumas das finalidades previstas no n. ${ }^{0}$ 2, 0 que the conferirá legitimidade e, por fim (esta a questão central e mais complexa), a ponderação sobre a necessidade imperiosa dessa medida numa sociedade democrática para alcançar o fim ou fins ali previstos ${ }^{27}$.

No conceito de "ingerência" podem integrar-se circunstâncias como condenações judiciais no âmbito de um processo penal, quer seja por crimes de difamação, de violação de segredo de justiça ou de desobediência, bem como de condenações em processo civil por ofensas à honra e bom nome e prestígio ${ }^{28}$.

Neste precário e constante equilíbrio entre os interesses em jogo, nem tudo é previsível, nem tudo é unívoco e, não raro, nem tudo é coerente e muito menos unânime, 0 que se traduz em divergências de posições entre os próprios juízes do TEDH (frequentemente havendo decisões maioritárias por margens mínimas), além de haver flagrantes divergências entre as decisões das instâncias nacionais e as do TEDH. Trata-se, com efeito, de intervir sobre 47 ordenamentos jurídicos, com dissemelhanças grandes entre si, desde sistemas que já descriminalizaram a difamação até sistemas que continuam a prever penas de prisão para a difamação, desde sistema mais punitivistas a sistemas mais garantísticos, o que nem sempre conduz às soluções - sempre concretas - mais previsíveis, tendo em conta tal estado de coisas.

0 TEDH tem preferido não assentar em princípios ou doutrinas gerais sobre matérias, antes se sustentando em decisões individuais, apreciando as situações caso a caso, em função da diversidade dos ordenamentos internos nacionais, e das concretas situações a ajuizar, formulando assim, decisões casuísticas, sem apelar a precedentes de matriz anglo saxónica.

\footnotetext{
${ }^{27}$ Criticando a metódica do casuísmo do TEDH, a propósito do caso Lopes Gomes da Silva c. Portugal, de forma acutilante, FARIA COSTA refere que «Não é suficiente - sobretudo quando se joga, repete-se, nos confins - dizer que uma determinada acção não viola um preciso e particular bem jurídico, um direito fundamental; é, para além disso, absolutamente imperioso também afirmar quando é que ele é violado ou ofendido. Ou (...) então, o que se torna obrigatório, necessário e impressindível é dar um critério material que permita, com razoabilidade perceber os limites positivos e negativos da situação que se valora e que se tem ou não de considerar como violadora de um direito fundamental» («Tribunal Europeu dos Direitos Humanos (caso Lopes Gomes da Silva c. Portugal - queixa n. ${ }^{0} 37$ 698/97), loc. cit., p. 152.

${ }^{28}$ Para uma sistematização das causas processuais dos casos portugueses de violação do art. 10. ${ }^{\circ} \mathrm{da}$ CEDH, cr. Raquel S. Pires Antunes Cruz, A jurisprudência do artigo 10.ำ da Convencão Europeia dos Direitos do Homem nos casos portugueses, Dissertação de Mestrado apresentada à Faculdade de Direito da Universidade de Coimbra, 2016, disponível no repositório digital da Universidade de Coimbra.
} 
ULP Law Review | Revista de Direito da ULP

Vol. 13, n. .9

doi:10.46294/ulplr13n 1 ga3

Um acórdão do Tribunal da Relação de Lisboa, de 26 de janeiro de 2017 (Relator: Desemb. Vítor Morgado) ${ }^{29}$ suscitou a questão de saber se os tribunais portugueses devem acolher em todos os casos o sentido da jurisprudência do TEDH, relativamente à tutela da honra de figuras públicas. A questão assume interesse e atualidade, podendo decompor-se em duas sub-questões: (i) apreciar o valor da interpretação das normas da CEDH feita pelo TEDH como fonte de direito e (ii) avaliar se essas interpretações podem, ou não, ser violadoras da Lei Fundamental nacional.

0 nosso ordenamento jurídico assenta numa matriz romano-germânica, em contraposição à regra do precedente obrigatório. Nesse ponto de vista, os precedentes jurisprudenciais emanados pelo TEDH não vinculam diretamente as instâncias nacionais, com exceção dos processos em que o próprio Estado Português seja parte (art. 46. ${ }^{\circ}$ n. ${ }^{0} 1$ da $\left(E D H^{30}\right)$. 0 TEDH não funciona com poderes de cassação, e, como se sabe, as suas decisões não interferem, por regra ${ }^{31}, 0$ caso julgado das decisões internas e concretamente questionadas no processo. Contudo, as correntes de jurisprudência crescentemente consolidadas do TEDH vinculam indiretamente os tribunais nacionais na aplicação das normas que afetem os direitos humanos consagrados na Convenção. Assim, conquanto a jurisprudência do TEDH não seja expressamente uma fonte de direito, constitui indiscutivelmente um parâmetro de interpretação jurisprudencial atualista e privilegiado do sistema de direitos humanos plasmado na CEDH.

Acresce a isso a progressiva relevância do efeito persuasivo do número das decisões concordantes com precedentes - sobretudo se provenientes de tribunais superiores - e que induzem um acrescido grau de convencimento pela maior probabilidade do seu acerto, conferindo-lhe a necessária legitimidade; são, de resto, conhecidas posições do STJ ${ }^{32}$, no

\footnotetext{
29 Já anteriormente, outro aresto da mesma Relação se inclinou para a mesma solução: 0 ac. $R$ Lx 12.05.2016 (relator: Desemb. Antero Luís) apontara já para uma eventual inconstitucionalidade da jurisprudência TEDH quanto à interpretação do art. 10. ${ }^{\circ},{ }^{0}{ }^{0} 2$ da CEDH, por violação do regime dos artigos $16 .{ }^{0},{ }^{0}{ }^{0} 2$ e 18. ${ }^{\circ}$ n. ${ }^{0} 3$ da CRP, ao hierarquizar preferencialmente 0 direito à liberdade de expressão em posição superior à dos direitos à honra e ao bom nome e esvaziar, assim, 0 conteúdo destes face ao daquele. ${ }^{30}$ Nomeadamente os processos em que os Estados contratantes sejam demandados por particulares, justamente em virtude de queixas por violação de direitos humanos por parte de autoridades nacionais. ${ }^{31}$ Cfr. supra [nota 25].

${ }^{32}$ Cfr., por todos, Ac. STJ de 12.05.2016, proc. 982/10.4TBPTL.G1-A.S1 (relator Cons. Abrantes Geraldes), em que equaciona os termos do valor reforçado dos acórdãos uniformizadores de jurisprudência - que
} 
ULP Law Review | Revista de Direito da ULP

Vol. 13, n. .9

doi:10.46294/ulplr13n 1 ga3

sentido de que os tribunais que profiram decisões opostas ou diversas de correntes jurisprudenciais consolidadas, estão obrigados ao cumprimento de um dever de fundamentação acrescido.

\subsection{Um "ordenamento paroquia|"?: a jurisprudência tradicionalista e a jurisprudência progressista}

Existe, porventura com algum grau de generalização, a ideia de que os tribunais nacionais, em matéria de julgamento de factos atentatórios da honra e do bem concretamente perante acusações de crimes de difamação, injứria e calúnia - adotam cânones de apreciaçãa e ponderação de direitos conflituantes que se distanciam dos critérios que o TEDH vêm acolhendo em tais domínios.

É uma perspetiva defendida por alguns Autores ${ }^{33}$, a qual não sufragamos na sua integralidade, uma vez que tem havido claros exemplos de decisões jurisprudenciais que desmentem essa alegada tendência preponderante.

É claramente 0 caso do Ac da Relação do Porto de 31.10.2007 (relator: Desemb. António Gama) ${ }^{34}$, em que se colocou a questão da qualificação jurídico-criminal do epíteto "energúmeno" a um presidente de câmara municipal, utilizado por cronista de um diário com expansão nacional num dos escritos em tal jornal.

Depois de circunstanciadamente enquadrar os termos da solução do conflito em presença nos autos, designadamente com recurso à doutrina das decisões do TEDH em matéria de liberdade de expressão, e reconduzindo a questão nodular aos limites do livre

emerge da composição do Pleno das secções (cíveis, criminais ou social) do STJ, bem como de o seu não acatamento pelos tribunais das instâncias inferiores constituir motivo especial para a admissibilidade de recurso, de resto obrigatório para o Ministério Público (art. 446. ${ }^{\circ}, \mathrm{n} .{ }^{0} 2$ do (PP) -, em contraposição ao valor de fonte de direito anteriormente conferido aos assentos, nos termos do art. $2 .{ }^{\circ}$ do CC.

${ }^{33} \mathrm{Cfr}$. por todos, FRANCISCO TEIXEIRA DA MOTA, em 0 Tribunal Europeu dos Direitos do Homem e a Liberdade de Expressão - Os casos portugueses, Coimbra, Coimbra Ed., 2009 e A Liberdade de Expressão em Tribunal, Lisboa, Fundação Francisco Manuel dos Santos, 2013.

${ }^{34}$ Consultável em:

http://www.dgsi.pt/itrp.nsf/dld5ce625d24df5380257583004ee7d7/d408110c8eb4243d8025738a0051 2058? 0penDocument. 
ULP Law Review | Revista de Direito da ULP

Vol. 13, n. .1

doi:10.46294/ulplr13n1ga3

exerćicio do direito à crítica, no acórdão refere-se de forma que ainda hoje se mantêm atuais e prospetivos:

«(...) Energúmeno, no sentido que 0 arguido admitiu ter usado - ignorante e boçal, em termos de políitca e gosto cultural, que pratica destinos [a defesa/exigência da demissão de E..................], e que esta sua última atitude se insere numa lógica repressiva de silenciamento, à cata de "delito de opinião" -, que é o que releva em virtude da aplicação do princípio in dubio pro reo, pode suportar uma crítica objectiva. (...) A expressão, com 0 sentido de ignorante ou mesmo boçal em matéria cultural, não é dirigida contra a pessoa do ofendido mas contra o dirigente políitico da maioria que governava a Câmara Municipal do Porto, contra o seu presidente. (...) Isto não significa que os jornalistas estão dispensados, como por vezes se ouve, de obediência à lei. Numa sociedade democrática não vigora 0 «vale tudo». Agora numa sociedade democrática, a crítica é um exercício de cidadania, de que não se deve ter medo e muito menos perseguir penalmente, se a mesma se contém dentro dos limites lícitos, que são suficientemente amplos como vamos ver, quando estão em causa questões de interesse público. (...) Decidir os limites da crítica legítima é por vezes difíicil. 0 arguido não foi delicado na sua crítica, sendo certo que o direito penal não trata, como já enfatizamos, dessa dimensão dos comportamentos. Mas também não nos parece ocorrer ataque pessoal gratuito: 0 artigo de opinião em causa é apenas mais um, em que o recorrente desanca de modo desabrido a política cultural do ofendido, que na opinião do recorrente era errada. Importa não esquecer a importante e pertinente distinção, que S. Ruhdie estabelecev: atacar pessoas é uma coisa, criticar as suas crenças ou as suas ideias é outra. Na nossa sociedade democrática, a crítica é um exercício indispensável de cidadania, de que não se deve ter medo e muito menos perseguir; a crítica legítima, está bom de ver. Ora a crítica que o arguido levou a cabo, a respectiva acção, não é sequer penalmente típica pelo que se impõe a sua absolvição». 
ULP Law Review | Revista de Direito da ULP

\author{
Vol. 13, n. .9 \\ doi:10.46294/ulplr13n1 ga3
}

Pensamos que este - e não é o único ${ }^{35}$ - é um excelente exemplo de uma decisão jurisprudencial que ultrapassou já os termos de um atavismo "paroquial" e anacrónico, registando-se, contudo, a posição ali também enunciada, que nos parece ser a mais adequada, no sentido de o âmbito de proteção do direito ao bom nome e reputação não ser menos intenso na esfera pública (v.g. na atividade política) do que na esfera estritamente pessoal. 0 que sucede, como também realçamos, é que a «ponderação e balanceamento» dos direitos é sempre feita por referência a direitos fundamentais que não

${ }^{35}$ De que são exemplos mais recentes os Acórdãos da RE de 26.06 .2018 (Relator: Desemb. António Condesso), de 07.03.2017 (Relator: Desemb. Alberto Borges), e de 01.07.2014 (Relator: Desemb. João Gomes de Sousa): em que se destacam, pela sua relevância, os seguintes excertos do sumário «ll. A Convenção para a Protecç̧̃̃o dos Direitos do Homem e das Liberdades Fundamentais (vulgarmente designada como Convenção Europeia dos Direitos do Homem) vigora na ordem juríica portuguesa com valor infraconstitucional, isto é, com valor superior ao direito ordinário português. III. Considerando a adesão de Portugal à Convençã̃o e o teor do art. $8 .{ }^{\circ}$ da Constituiç̧̃ó da República Portuguesa, a não aplicação da Convenção, enquanto direito interno português de origem convencional, é um claro erro de direito. IV. A apreciação valorativa do confronto entre a liberdade de expressão e a honra é feita em sede infraconstitucional pela Convenção e pelo ordenamento penal português, e não no patamar constitucional, o que torna a Convenç̧̃o um pilar essencial de onde se deve partir para a análise criminal em casos que exijam a sua aplicação. V. A Convenção faz uma clara opção na definiç̧ão da maior relevância do valor «liberdade de expressão» sobre o valor «honra». Ou seja, a «ponderação de valores» é normativa, já foi feita pela Convenção com uma clara preferência pelo valor «liberdade de expressão». VI. A liberdade de expressão só pode ser sujeita a restriçōes nos termos claros e restritivos do n. ${ }^{2} 2$ do art. 10. ${ }^{\circ}$ da Convenção, pelo que as «formalidades, condiçoes, restriç̄ôes e sanç̄oes» á liberdade de expressão devem ser convenientemente estabelecidas, corresponderem a uma necessidade imperiosa e interpretadas restritivamente (Decisão Sunday Times, 26-04-1979, § 65). VII. A tutela da honra deve situar-se na análise dos tipos penais de difamaç̧̃o no momento lógico de análise do n. ${ }^{0} 2$ desse art. 10. ${ }^{\circ}$. VIII. Esse art. $10 .{ }^{\circ}$ é um pilar, não apenas de reconhecimento de direitos individuais, mas muito mais relevantemente de reconhecer que há direitos individuais que são o cimento de um determinado tipo de sociedade, a sociedade democrática, juridicamente Estado de Direito. IX. Se no geral prevalece como direito maior a liberdade de expressão pela sua essencialidade democrática, no campo da luta políitca e questōes de "interesse geral" a tutela da honra é residual. É jurisprudência convencional constante a afirmação de que no campo da luta e discurso políico ou em questōes de interesse geral «pouco espaço há para as restriçōes à liberdade de expressão». X. Na análise do n. ${ }^{2} 2$ do art. $10^{\circ}$ da Convenção é necessário saber se existem os requisitos de punibilidade ali contidos: se a restrição à liberdade de expressão estáa «prevista na lei» (aqui através do tipo penal de difamação) e prossegue um «objectivo legíímo» (aqui a tutela da honra) e se a condenação do arguido se justifica, se é uma «providência necessária numa sociedade democrática». XI. A expressão «providência necessária numa sociedade democrática» tem sido interpretada pelo Tribunal Europeu dos Direitos do Homem como a exigência de uma «necessidade social imperiosa» que justifique uma condenação. XII. A natureza e a medida das penas infligidas pela prática de crimes de difamação são elementos a ter em consideração quando se trata de medir a proporcionalidade da ingerência na liberdade de expressão. XIII. Neste sentido, a aplicação de penas de prisão não se justifica nos crimes de difamação, excepto em circunstâncias excepcionais, designadamente se outros direitos fundamentais foram gravemente atingidos, como nos casos de incitamento á violência, de discurso de violência contra pessoas ou grupos, de incitamento ao ódio e de apelo á intolerância. XIV. 0 Tribunal Europeu dos Direitos do Homem na recente decisão Amorim Giestas e Jesus Costa Bordalo c. Portugal (3 de Abril 2014, § 36) é claro em considerar que 0 ordenamento juríico português contém um remédio espećfíco para a protecção da honra e da reputação no art. 70. ${ }^{\circ}$ do Código Civil, pelo que a penalização por difamação se deve entender hoje como residuals. 
ULP Law Review | Revista de Direito da ULP

Vol. 13, n. .9

doi:10.46294/ulplr13n 1 ga3

são coincidentes; se de um lado está sempre a honra, a consideração ou o bom nome, do outro pode estar só a liberdade de expressão ou a liberdade de expressão e a liberdade de imprensa.

\subsection{Metódicas de ponderação e de resolução de conflitos}

A propósito dos limites à liberdade de expressão, importa relembrar os esforços já empreendidos no sentido da tendência para descriminalização da difamação na Europa, em resultado de persistentes recomendaç̃oes do Comité dos Direitos do Homem das Naç̃ões Unidas $^{36}$, do Conselho de Europa ${ }^{37}$ e das decisões do TEDH ${ }^{38}$, que pretendem relegar crescentemente 0 tratamento da questão para o domínio do ilíito civil.

De entre outros fundamentos para a abolição da criminalização da difamação, a Resolução 1577 (2007) e a Recomendação 1814 (2017) para uma descriminalização da difamação, da Assembleia Parlamentar do CdE, salientavam, a utilização da criminalização da difamação por alguns Estados como forma de silenciarem a crítica dos Media, reduzindo o debate democrático, preconizando a inaceitabilidade da pena de prisão prevista para profissionais da comunicação social, como entrave à liberdade de expressão, pelo que tal pena deveria ser imediatamente abolida, solicitando a definição precisa e uniforme do conceito de difamação, reservando a direito civil a tutela efetiva da dignidade das pessoas afetadas pela difamaç̃ão. Além disso, apenas deveria tipificar-se como crime 0 incitamento público à violência, ao ódio ou discriminação, ou a ameaça a pessoa ou grupo de pessoas

\footnotetext{
${ }^{36}$ Cfr., Comentário Geral n. ${ }^{\circ}$ 34, de 12.09.2011: «[0]s Estados partes devem considerar a possibilidade de descriminalizar a difamação e, em qualquer caso, as normas penais apenas devem ser aplicadas nos casos mais graves, nunca sendo adequada a pena de prisão».

${ }^{37}$ Resoluçãa 1003 (1993) sobre ética em jornalismo; Recomendação 1589 (2003) sobre liberdade de expressão nos media na Europa, Resolução 1535 (2007) sobre ameaças à liberdade de expressão de jornalistas, Resolução 1577 (2007) para a descriminalização da difamação, e a Recomendação 1814 (2017) para uma descriminalização da difamaç̃ão, solicitando ao Comité de Ministros a elaboração de um projecto de Recomendação para erradicar o recurso abusivo a processos-crime. Cfr. pertinente documentação em «Por uma descriminalização da difamação - Conselho da Europa», Ano 29. . N. ${ }^{\circ}$ 114, abr.jun., 2008, pp. 215 a 224.

${ }^{38}$ Entre outras, ilustrativamente, só por respeitarem a Portugal, Ac. Amorim Giestas \& Jesus Costa Bordalo c. Portugal, n. ${ }^{0}$ 37840/10, de 03.04.2014, conduindo que para as ofensas a honra e a reputaçãa a tutela constante do art.70. ${ }^{\circ}$ do Código Civil é bastante, sendo a criminalização por difamação apenas para casos excecionais, como os discursos de ódio ou incitamento a violência.
} 
ULP Law Review | Revista de Direito da ULP

Vol. 13, n. .9

doi:10.46294/ulplr13n 1 ga3

por razões de raça, cor, língua, religião, nacionalidade ou origem étnica ou nacional, desde que tais comportamentos sejam praticados de forma deliberada. A previsão da pena de prisão deveria circunscrever-se, contudo, apenas ao incitamento à violência, ao discurso de ódio ou à promoção do negacionismo. Outrossim, deveriam remover-se quaisquer proteções acrescidas para figuras públicas, de acordo com a jurisprudência do TEDH. Deveriam estabelecer-se quantias máximas, razoáveis e proporcionais para as indemnizações em caso de difamação, por forma a não pôr em causa a viabilidade de um órgão de comunicação social responsabilizado.

Refira-se, todavia, que em resposta à Recomendação 1814 (2007) da Assembleia Parlamentar do CdE, o Comité de Ministros não se revelou igualmente entusiástico quanto aos pressupostos e objetivos da mesma, tendo na 1029. . Reunião dos Delegados dos Ministros (de 11.06.2008) emitido uma posição muito menos ambiciosa, no sentido de apelar à adoção de medidas tendentes a remover riscos de sanções abusivas ou injustificadas por difamaçãa, mas considerando não ser oportuno desenvolver regras específicas sobre a descriminalização da difamação para os Estados contratantes, não sendo também necessário alterar a recomendação n. ${ }^{0} R$ (97) 20 sobre discurso de ódio, devendo, antes, ser empreendidos mais esforços pelos Estados contratantes no sentido de tornar esta mais efetiva.

Em qualquer caso, realçou a importância da jurisprudência papel do TEDH no tocante ao art. $10^{\circ}$ da CEDH a propósito do desenvolvimento dos princípios gerais sobre difamação. Atualmente, de entre os (ainda) 28 Estados-Membros da EU, seis já aboliram a criminalização da difamaçãa ${ }^{39}$ e, dos restantes, três não prevêem a pena de prisão para este crime ${ }^{40}$.

Convém, ainda recordar 0 apelo do Internacional Press Institute feito a Portugal em 2015 no sentido de se suprimir a pena de prisão para o crime de difamação e 0 agravamento das penas quando os ofendidos sejam titulares de cargos públicos, constante

\footnotetext{
${ }^{39}$ Reino Unido, a Irlanda, Estónia, Roménia, Finlândia e Chipre. Também dois dos cinco estados candidatos oficiais (Montenegro e Antiga Republica Jugoslava da Macedónia) descriminalizaram a difamação.

${ }^{40}$ Franca, Croácia e Bulgária, aos quais se poderá juntar no futuro a Sérvia, candidata oficial.
} 
ULP Law Review | Revista de Direito da ULP

Vol. 13, n. .1

doi:10.46294/ulplr13n 1 ga3

do art. $184 .^{\circ}$ do $\mathrm{CP}^{41}$. Por último, cremos ser igualmente imperativo que o legislador acompanhe os "critérios europeus de resolução do conflito" que o TEDH vem decantando desde há muito, prevendo-se a relevância da prova da verdade dos factos e da boa-fé no direito civil.

Devem essas linhas normativas de decisão generalizáveis, ir ao encontro das teses que defendem que as decisões de ponderação de direitos fundamentais devem assentar na "construção de uma rede de juízos de precedência traduzidos em regras progressivamente densificadas e estabilizadas de decisão dos casos concretos ${ }^{1142}$.

Como se deixou intuir, o princípio da concordância prática pressupõe uma maximização da proteção de cada um dos direitos em confronto, comprimindo-se reciprocamente de forma proporcional. Porém, nem sempre será viável (ou exequível) obter a otimização do âmbito de proteção dos direitos em confronto. Há situações que inequivocamente aconselham o recurso a soluções de "prevalêncid" ou "preponderância", impossibilitando a adoção da medida menos lesiva para 0 direito restringido. Concretizando, quando o direito prevalecente for a liberdade de expressão, a resolução do conflito nem sempre se coadunará com a medida "menos gravosa" para a honra ou para 0 bom nome do visado. Assim, se numa peça jornalística se disser que uma figura com projeção pública praticou factos que configuram um crime de corrupção, em termos lesivos da sua honra, as concretas circunstâncias do caso poderão justificar que 0 interesse público da notícia dispense a compatibilização dos direitos, no sentido de serem omitidas as palavras desonrosas ou a própria identidade da pesso $\mathrm{a}^{43}$.

A nossa jurisprudência maioritária aponta, na senda de significativa doutrina ${ }^{44}$, para a adoção de critérios de equivalência do direito à liberdade de expressão e do direito à honra

\footnotetext{
${ }^{41}$ V. Relatório: Criminalização da Difamaç̧a em Portugal de junho de 2015 do Instituto Internacional da Imprensa, disponível em http://legaldb.freemedia.at/.

${ }^{42}$ JORGE REIS NOVAIS, Direitos Fundamentais e Justica Constitucional..., cit., p. 83

${ }^{43}$ Como paradigmaticamente refere JONATAS MACHADO, «(...) pode ser desproporcional exigir-se um absoluto respeito pelo princípio da proporcionalidade» (Liberdade de Expressão. Dimensões Constitucionais da Esfera Pública no Sistema Social, Studia lvidica 65 - BFDUC, Coimbra, Coimbra Editora, 2002, p. 739).

${ }^{44}$ Assim, COSTA ANDRADE, Liberdade de Imprensa e Inviolabilidade Pessoal, Uma perspectiva JurídicoCriminal, Coimbra, Coimbra Ed., 1996, p. 299; GOMES CANOTILHO E VITAL MOREIRA, que afirmam: «(...) o âmbito do direito ao bom nome e reputação não é menos intenso na esfera políica do que na esfera
} 
ULP Law Review | Revista de Direito da ULP

Vol. 13, n. .1

doi:10.46294/ulplr13n 1 ga3

e ao bom nome, não atribuindo uma prevalência de princípio àquela sob pena de violaçã̃o

do art. 18. ${ }^{\circ}$, n. ${ }^{0} 2$ da Constituiçãa ${ }^{45}$. Nesse sentido, tem-se situado maioritariamente, numa posiçãa de alguma relutância da aceitação da jurisprudência do TEDH neste domínio.

Como COSTA ANDRADE já lembrou, «Muitos dos bens jurídicos pessoais que acabam de atrair a tutela penal revelam uma vocação ostensivamente conflitual. Na expressiva formulação de Eser, estes bens jurídico-penais são invariavelmente portadores duma "imanente colisão de valores»"

Deve lembrar-se que a defesa da aplicação de critérios de prevalência do direito à liberdade de expressão face ao direito à honra e ao bom nome, preconizado pela jurisprudência do TEDH, parte do pressuposto, porventura controverso, de que se reconhece a igual dignidade de ambos esses direitos fundamentais. Todavia, na resolução concreta do

pessoal, devendo ser harmonizado e balanceado com a liberdade do debate políico e com a liberdade de crifica política, que são inerentes à democracia. Neste aspecto, o TEDH tem adoptado um critério assaz liberal na protecção da liberdade de expressão e opinião e do direito de crítica pollitica em desfavor do bom nome e reputacáa políica dos titulares de cargos políicicos ou dos agentes políticos. No contexto constitucional português, os direitos em colisão devem considerarse como principios susceptiveis de ponderação ou balanceamento nos casos concretos, afastando-se qualquer ideia supra ou infravaloração abstractar) (Constituicão da República Portuguesa Anotada, Coimbra, Coimbra Ed., Vol. I, 4. ${ }^{-}$ed., rev. reimp., 2014, p. 466); IOLANDA RODRIGUES DE BRITO aponta também como critérios a uilizar em tal ponderaçã̃o, em matéria de colisão entre o direito à honra e a liberdade de expressão, a prossecusção de um interesse público; a verdade/falsidade do facto imputado e a gravidade do juízo de valor; Segundo esta autora «mesmo em relacão às figuras públicas há limites que não podem ser ultrapassados, ainda que no domínio da esfera pública. A tolerância à crítica tem que conhecer barreirras, sob pena de se negar, de uma forma intolerável, a protecç̃̃o da honra das figuras públicas, o que poderia acarretar diversas consequências negativas, nomeadamente afastar as mais dignas da vida pública". Esta protecção é especialmente exigida, "se uma figura pública pauta o seu comportamento público por padrões de correcção, urbanidade, honestidade e lealdade merece uma maior protecccão da sua honra do que a figura pública que assume uma conduta pouco compativel com aqueles padrõess) (Liberdade de Expressão e Honra das Figuras Públicas, Coimbra, Coimbra Ed., 2010, pp. 258-259). Este mesmo critério de prossecução de interesse público, já foi utilizado, jurisprudencialmente, pelo STJ no acórdão de 03.03.2005, para ponderação entre ambos os direitos em conflito, tendo decidido que «A liberdade de expressc̃o não pode (e não deve) atentar, contra o direito ao bom nome e reputação, salvo quando estiver em causa um interesse público que se sobreponha àqueles e a divulgação dos factos seja feita de forma a nõo exceder o estritamente necessário a tal salvaguardà.

${ }^{45}$ Posição que vem sendo reafirmada por jurisprudência constante do STJ, p. ex. nos Acórdãos de 07.03.2002 - Relator: Cons. Oliveira Barros; de 03.06.2009 - Relator: Cons. Rodrigues da Costa, e de 14.01.2010 - Relator: Cons. Pires da Rosa.

${ }^{46}$ Liberdade de Imprensa e Inviolabilidade Pessoal, Uma perspectiva Juridico-Criminal, Coimbra, Coimbra Ed., 1996, p. 28. 
ULP Law Review | Revista de Direito da ULP

Vol. 13, n. .9

doi:10.46294/ulplr13n1ga3

seu eventual confronto, 0 elemento decisivo para a solução do conflito seria 0 interesse público das questões que podem colocar em causa a honra ou o bom nome.

Pensa-se, por isso, que na aplicação dos cânones interpretativos do art. 10. ${ }^{\circ}$ da CEDH, quando estejam em causa conflitos entre do direito à liberdade de expressão e o direito à honra ou ao bom nome, não pode ignorar-se a disciplina do art. $18 .{ }^{\circ}$ da CRP, apesar de se procurar fazer uma aplicação atualista e evolutiva do conteúdo dos direitos fundamentais em questão.

A metódica adequada dentro de uma lógica de compatibilização, deve passar pela consideração dos bens jurídicos que em concreto sejam tutelados pelos direitos fundamentais em conflito ${ }^{47}$.

Podemos, pois, concluir pelo princípio de aplicação de uma metódica dos critérios de concordância prática e de maximização do conteúdo dos direitos fundamentais quando 0 direito à liberdade de expressão (e de informação) conflitua com outros direitos fundamentais, admitindo, de princípio, a hipótese de prevalência do mesmo, em circunstâncias que concretamente dispensem a procura (e obtenção) de um tal ponto de equilíbrio, nomeadamente quando esteja em causa um interesse ostensivamente público na base da divulgação de certo facto, mesmo que não devidamente averiguado ou demonstrado, ou opinião, mesmo que grave.

Do mesmo passo, não estamos convencidos de que a operação de prevalência deva prosseguir sempre uma opção em favor do direito da liberdade de expressão, podendo também reconduzir-se à aceitação da sua postergação, nos casos de comprovada falsidade, inutilidade ou quando as notícias, factos ou opiniões sejam desprovidas de interesse público.

A criação de normas jurídicas mais claras e densificadas contribuiria certamente para a harmonização de julgados e para uma melhor aplicação do Direito, sem desprimor para os esforços hermenêuticos do TEDH no sentido de alcançar uma interpretação mais próxima

\footnotetext{
${ }^{47}$ Como exemplo, a tutela da liberdade de expressão há-de ser tanto mais intensa quanto mais acentuada for a sua incidência nos princípios da dignidade da pessoa humana e do Estado de direito democrático, mormente quando esteja em causa um interesse público forte.
} 
ULP Law Review | Revista de Direito da ULP

Vol. 13, n. .9

doi:10.46294/ulplr13n 1 ga3

dos propósitos da CEDH, que atravessou - e atravessará - décadas nas quais ocorreram transformações a todos os níveis, acompanhando a evolução nos planos das convicç̃óes e das ideias.

\section{Implicaçōes dos novos meios digitais de difusão de informação e de opiniõo na liberdade de expressĩo}

Todas a consideraçoces acima expostas são válidas para as realidades das formas convencionais de meios de comunicação social no que respeita à equaç̧õo entre a liberdade de expressão e de informação e os direitos fundamentais com a honra e 0 bom nome; quer a CEDH (e seu artigo 10.9) quer praticamente toda a jurisprudência referencial do TEDH nestes domínios, foram elaborada e produzida sem considerar as implicações das novas tecnologias de comunicação e informação (e, no caso da CEDH, sem o conhecimento ou intuição do impacto destas).

Em rigor, no que toca aos meios de comunicação formalmente constituídos e que optem pelo meio digital, serão previsivelmente escassas as alteraçóes a introduzir a este respeito. Pode dizer-se que todo o complexo normativo e jurisprudencial do quadro da CEDH será transponível - e, portanto, aplicável - à atividade dos novos Media digitais.

Questão mais controversa será a sua aplicabilidade a meios de informaç̃ã digital informais.

Na verdade, se a Internet é um campo de oportunidades de informação e de formação, também pode converter-se num vasto território de difusão de falsidades, de calúnias e de discursos discriminatórios e de ódio, sem que se torne viável imputar a responsabilidade com alguma certeza e rigor. A Internet pode, a mesmo tempo que exponencia a difusuão da informação negativa ou nefasta - com a possibilidade virtualmente infindável de replicação de mensagens por um número significativamente superior aos dos leitores de jornais e das assistências televisivas -, servir de reduto de impunidade dos seus responsáveis. 
ULP Law Review | Revista de Direito da ULP

Vol. 13, n. .9

doi:10.46294/ulplr13n1ga3

Donde, haver a necessidade e urgência em aprofundar 0 debate em torno dos termos normativos da utilização dos meios de comunicação digital, excluindo a sua proibição e procurando saber se é possível, de alguma forma, adaptar 0 conteúdo dos entendimentos jurisprudenciais do TEDH à sua atividade, quando se coloquem problemas de colisão entre a liberdade de expressão e de informação e os direitos fundamentais potencialmente afetados com o seu exercício através de tais meios.

É sabido que na atualidade, 0 impacto de um «tweet» de um alto dirigente de um País pode ter efeitos económicos e sociais surpreendentemente inesperados e desproporcionados. São noticiadas versões sobre interferências por potências estrangeiras, através de manipulaçã̃o eletrónica, em processos eleitorais de países com tradições democráticas solidificadas. Surgem notícias sobre o condicionamento da opinião pública através de redes sociais em aparente violação de regras de isenção e igualdade de oportunidades do processo eleitoral. Enfim, todo um novo cenário emerge envolvendo questões que transcendem a conformação da atividade da comunicação social convencional, com efeitos à distância e de amplitude inesperada ${ }^{48}$.

A crescente utilização de formas diretas de comunicação digital por dirigentes políticos, empresariais, desportivos, culturais integra a estratégia de secundarizaçãa ou anulação da função de mediaçãa ou filtragem dos meios de comunicação social para, assim, suprimirem instâncias de escrutinio através da crítica e da opinião. Os poderes políiticos também aproveitam oportunidades para relativizar a importância da função [mediadora] de formação da opinião pública que os Media desempenham numa sociedade democrática através de tentativas da sua descredibilização, do que também assistimos a exemplos eloquentes.

É claro que a divulgação digital de informação com recurso à Internet também pode encerrar um potencial de oportunidades de aprofundamento da função crítica e de

\footnotetext{
${ }^{48}$ Para uma visão integrada sobre os problemas da sociedade de informação e 0 impacto da comunicação digital em geral, cr. MANUEL CASTELLS, Galáxia Internet-Reflexões sobre Internet, Negócios e Sociedade, Lisboa, FCG, 2004 e Communication Power, Oxford University Press, 2013.
} 
ULP Law Review | Revista de Direito da ULP

Vol. 13, n. .1

doi:10.46294/ulplr13n 1 ga3

escrutínio dos Media ${ }^{49}$. Basta, a este propósito, lembrar a função de intensificação de campanhas de escrutínio de atividades ilícitas dos Estados por ONG, em que se inclui, p. ex. a Wikileaks ${ }^{50}$, ou plataformas como a Avaaz ${ }^{51}$. Um relatório sobre Liberdade na Internet de 2011 demonstrou a existência de crescentes ameaças à liberdade na internet através de bloqueio de conteúdos, ataques cibernéticos contra as críticas aos regimes e censura. As menores interferências registam-se na Estónia, EUA, Alemanha e Austrália, sendo maiores no lrão, Birmânia, Cuba e China (RPC) 52 .

Por seu turno, o Conselho da Europa vem assumindo a liderança no que concerne à elaboração de declarações e diretrizes sobre a aplicação dos direitos humanos na internet, como a "Declaração sobre Direitos Humanos e a Internet", de 2005, e a "Declaração sobre a proteção da liberdade de expressão e da liberdade de reunião e de associação no que diz respeito às plataformas de internet operadas por privados e aos prestadores de serviços em linha", de dezembro de 2011. Também se prevê para breve a adoção de diretrizes de Direitos Humanos para motores de pesquisa e redes sociais.

Em janeiro de 2012, a Comissão Europeia apresentou uma proposta de regulamento sobre a proteção de dados pessoais. Após um longo processo negocial, que se desenrolou com especial intensidade durante os anos de 2014 e 2015, aquela iniciativa legislativa veio a culminar na aprovação do Regulamento (UE) 2016/679, do Parlamento Europeu e do Conselho, de 27 de abril de 2016, relativo à proteção das pessoas singulares no que diz

\footnotetext{
${ }^{49}$ Convém não ignorar a questão da "iliteracia ou exclusão digital", o que coloca a questão da "solidariedade digital", considerando que mais de cinco biliões de pessoas em todo o mundo não tem acesso à internet e, em África, menos de 1\% da população total tem acesso.

${ }^{50}$ A Wikileaks recebeu o Prémio Meios de Informação da Amnistia Internacional do Reino Unido, em 2009. Em resposta às reações negativas de alguns Estados, a Alta Comissária das Nações Unidas para os Direitos Humanos manifestou a sua preocupação relativamente à "guerra cibernética" contra a Wikileaks, que foi alvo de um embargo financeiro (Cfr: Wikileaks, disponível em: wikileaks.org; UN News Centre. 2010. UN human rights chief voices concern at reported 'cyber war' against Wikileaks. Também disponível em: www.un.org/ apps/news/story.asp?newsid $=37009 \&(r \quad=$ leaked\&(rl). Os últimos desenvolvimentos relativos a esta organização e à detenção do principal dinamizador parecem oferecer um cenário assaz confuso sobre os efetivos propósitos e finalidades da mesma.

${ }^{51}$ Disponivel em http:www.avaaz.org.

${ }^{52}$ Cfr. Freedom House: Freedom on the Net, disponivel em: ww.freedomhouse.org/freedomonthenet 2011. Recorde-se que na Venezuela, que tem um dos números mais elevados de conexões à internet na América Latina, o presidente Hugo Chavez decretou, em 2009, que a internet no setor público era um luxo e que consistia uma despesa supérflua. Desde então, tem-se desenvolvido uma tendência de controlo da internet por razões políticas. (Cfr. Global Information Society Watch, disponível em: www.giswatch.org/).
} 
ULP Law Review | Revista de Direito da ULP

Vol. 13, n. .1

doi:10.46294/ulplr13n1ga3

respeito ao tratamento de dados pessoais e à livre circulação desses dados ${ }^{53}$. 0 dito

Regulamento passou a ser diretamente aplicável na ordem jurídica interna.

No capítulo dos "novos direitos" vem previsto 0 direito ao apagamento de dados - 0 "direito a ser esquecido" - e 0 direito à portabilidade adquirem especial relevo. A consagração de um "direito a ser esquecido", deverá, presuntivamente, conferir efetiva oportunidade aos utilizadores da Internet de ter um maior controlo sobre os seus dados pessoais.

Note-se, contudo, que 0 art. 17. ${ }^{\circ}$ do RGPD (direito ao apagamento de dados; «direito a ser esquecido») $)^{54}$ introduz no seu n. ${ }^{0} 3$ algumas exeções ao direito ao esquecimento, em que se incluem, justamente, situações em que 0 tratamento se revele necessário ao exerćcicio da liberdade de expressão e de informação (al. a)), ou para efeitos de declaração, exercício ou defesa de um direito num processo judicial (al. e)).

\footnotetext{
${ }^{53} 0$ RGPD revogou a Diretiva n. ${ }^{0}$ 95/46/CE e é aplicável em todos os Estados-Membros da União Europeia a partir de 25 de maio de 2018. № entanto, esta revogação não significa que tenha sido estabelecida uma rotura absoluta entre 0 sistema de proteção de dados pessoais consagrado nessa diretiva e 0 sistema adotado pelo RGPD. De facto, são muitas as situaç̧ōes de continuidade, e há definições fulcrais que não foram afetadas, como por exemplo as de dados pessoais, tratamento ou responsável pelo tratamento. Por seu turno, na presente data, encontra-se em fase de processo legislativo a Proposta de Lei n. ${ }^{0} 120 / X I I I$, em que se propõe a revogação da Lei n. ${ }^{0} 67 / 98$, de 26 de outubro, pelo que o regime jurídico fundamental aplicável em matéria de proteção de dados pessoais passou a ser, a partir de 25 de maio de 2018, o RGPD e a lei a aprovar.

${ }^{54}$ É 0 seguinte 0 teor dos n. ${ }^{\text {os }} 7$ e 2 do preceito: «l. 0 titular tem 0 direito de obter do responsável pelo tratamento 0 apagamento dos seus dados pessoais, sem demora injustificada, e este tem a obrigação de apagar os dados pessoais, sem demora injustificada, quando se aplique um dos seguintes motivos:

a) Os dados pessoais deixaram de ser necessários para a finalidade que motivou a sua recolha ou tratamento;

b) 0 titular retira 0 consentimento em que se baseia 0 tratamento dos dados nos termos do artigo $6 .{ }^{\circ}$, n. ${ }^{\circ}$, alínea a), ou do artigo 9.\%, n. 2, alínea a) e se não existir outro fundamento jurídico para o referido tratamento;

c) 0 titular opõe-se ao tratamento nos termos do artigo $21 .{ }^{\circ}$, n. ${ }^{\circ}$ l, e não existem interesses legítimos prevalecentes que justifiquem o tratamento, ou 0 titular opõe-se ao tratamento nos termos do artigo 21. , ก. ${ }^{2}$;

d) Os dados pessoais foram tratados ilicitamente;

e) Os dados pessoais têm de ser apagados para o cumprimento de uma obrigação jurííica decorrente do direito da União ou de um Estado-Membro a que o responsável pelo tratamento esteja sujeito;

f) Os dados pessoais foram recolhidos no contexto da oferta de serviços da sociedade da informação referida no artigo $8 .{ }^{\circ}$, n.. ${ }^{\circ}$.

2. Quando o responsável pelo tratamento tiver tornado públicos os dados pessoais e for obrigado a apagálos nos termos do n. ${ }^{\circ}$ l, toma as medidas que forem razóveis, incluindo de caráter técnico, tendo em consideração a tecnologia disponível e os custos da sua aplicação, para informar os responsáveis pelo tratamento efetivo dos dados pessoais de que 0 titular dos dados Ihes solicitou 0 apagamento das ligações para esses dados pessoais, bem como das cópias ou reproduçōes dos mesmos».
} 
ULP Law Review | Revista de Direito da ULP

Vol. 13, n. .9

doi:10.46294/ulplr13n1ga3

Por seu turno, saliente-se a grande expectativa que pode inspirar a recente aprovação pelo Parlamento Europeu (em 12.09.2018 ${ }^{55}$ ) da Diretiva da UE relativa aos Direitos de Autor no Mercado Único Digital ${ }^{56}$ em matéria de comunicação social, sendo óbvias as implicações que podem revestir na liberdade de expressão, mormente na amplitude e expansão do seu conteúdo, se lhe forem impostas restrições pecuniárias (a título de legítimas e devidas compensações aos titulares dos direitos de autor de muitos conteúdos que passarão a ser expressamente mais protegidos).

Outra inquietante implicação que pode surgir com a generalização dos modos de produção e informação digital está associada às modalidades de inteligência artificial na criação e construção de discursos nos ambientes automáticos digitais, em que a aplicação combinada dos desenvolvimentos das neurociências, da linguística e da machine learning pode permitir a construção de sistemas cognitivos que escapem em ampla medida ao controlo humano. Essa eventualidade pode constituir também um desafio sério à dogmática tradicional no sentido da determinação e imputação da responsabilidade criminal, individual ou coletiva.

0 que parece ser uma decorrência pouco discutível de todo este complexo cenário, é a necessidade de se equacionar uma reelaboração do catálogo e conteúdo material dos direitos humanos devido ao impacto do feixe de problemas colocados pela sociedade de informação e do ambiente digital. E, dentro, de tais preocupações, deverá pontificar a ponderação de uma reformulação do conteúdo do direito à liberdade de expressão e de informação em contexto e ambiente digital, face à eventualidade de as consequências dos crimes poderem ter efeitos muito mais perniciosos e extensos, virtualmente à escala global.

\subsection{A pulverização da responsabilidade e a inadequação dos mecanismos de}

regulação e sancionamento

\footnotetext{
${ }^{55}$ Aguardando-se na data da escrita do presente texto, a discussão e aprovação da versão final do documento pelo Parlamento Europeu e pelo Conselho.

56 Sendo conhecida a Proposta de Diretiva da Comissão COM(2016)0593 - C8-0383/2016 2016/0280(COD), de 14.09.2016, e conhecidas as alterações introduzidas na aprovação pelo Parlamento Europeu (P8_TA-PROV(2018)0337).
} 
ULP Law Review | Revista de Direito da ULP

Vol. 13, n. .1

doi:10.46294/ulplr13n1ga3

Os fenómenos da desterritorialização dos recursos tecnológicos dos meios de comunicação digital - sobretudo quando se consideram os meios de comunicaçãa e informação informais - colocam acrescidos problemas às instâncias policiais e judiciárias no tocante à investigação de eventuais ilícitos praticados através das respetivas plataformas e ao estabelecimento da responsabilidade dos seus agentes. Os principais problemas hoje enfrentados, são, essencialmente, os resultantes da deslocalização e desterritorialização das fontes de informação, que ocasionam dificuldades da própria investigação dos factos ilícitos e, no plano substantivo, a pulverização da responsabilidade dos seus agentes.

Ao nível da investigação, são colocados problemas de concurso de ordenamentos jurídicos - muitas vezes pouco compatíveis - e de mobilização de recursos tecnológicos dispendiosos, complexos e eficácia por vezes duvidosa. Por seu lado, os problemas surgidos no plano substantivo podem implicar um reequacionamento da própria dogmática jurídicocriminal e, na sua falência, apontar para a adoção de formas de condicionamento, a montante, das próprias atividades de difusão de informação e de opinião.

Importará, pois, a este nível, tentar encontrar respostas a inquietantes questões, p. ex., como localizar e documentar os suportes mediáticos em causa? Quem notificar e identificar como responsável? Que legislação substantiva aplicar? De acordo com que regras processuais de produção de prova proceder? Converter os operadores de servidores de serviços digitais em fiscais ou «polícias» da informação divulgada, impondo-lhes deveres de colaboração com as autoridades, e sob cominações sancionatórias (modelos de compliance mediática)? Responsabilizar e opor injunções judiciárias aos operadores de serviços de comunicações electrónicas que não cooperem voluntariamente? Responsabilizar (objetivamente) as entidades que pagam 0 serviço digital que veicula os atendados aos valores referidos, construindo modelos de "infrações formais"?

A isso acresce uma inescapável dificuldade probatória no tocante á investigação de condutas ilícitas contra os valores jusfundamentais tutelados, como a honra e 0 bom nome, o direito à palavra, à reserva da vida privada, à presunção de inocência. 
ULP Law Review | Revista de Direito da ULP

Vol. 13, n. .9

doi:10.46294/ulplr13n 1 ga3

Estes problemas, que apenas incipientemente aqui se intuem, comprometem todo um conjunto de conceções que se tem como válido e assente à luz de um paradigma normativo para 0 universo da comunicação social tradicional. Reclamam, por isso, outras equações e outras respostas. Algumas, julgamos que será possível extraí-las do sistema normativo jurídico-criminal e civilístico - vigente. Outras, porém, cremos que são insuscetíveis de se compatibilizar com os mecanismos jurídico-substantivos e processuais existentes, e terão de ser decantadas a partir de uma reflexão multidisciplinar.

\subsection{Um admiróvel mundo de fake news e fact checking.}

A mudança qualitativa dos modos de produção de informação - em espaços noticiosos convencionais (imprensa escrita, rádio, televisão, online) ou não convencionais - sítios de internet pessoais ou de grupos, blogs, redes sociais, caixas de comentários - é atravessada transversalmente por uma ameaça, que se vem convencionando chamar de "pós-verdade", com a crescente proliferação de fake news (notícias falsas); estas, podem traduzir-se em notícias parcialmente falsas, desinformação - i. e informação que, podendo ser verdadeira, é apresentada segundo filtros opinativos que pretendem manipular e condicionar a opinião pública -, ou, mesmo informação falsa, difundindo factos totalmente inventados.

Este quadro de manipulação da informação não é propriamente inédito, pois que são conhecidos de há muito os princípios e metodologias que guiaram e guiam a propaganda políica de muitos regimes políiticos, ou o marketing publicitário de muitas empresas.

A novidade é 0 meio onde se produzem (e replicam) as fake news - no ambiente digital online -, bem como as suas finalidades - orientadas de acordo com certos princípios ideológicos que pretendem desinformar sobre as mais variadas opções políiticoeconómicas, e manipular, condicionar, dessa forma, a opinião pública.

A verdade passa, assim, a ser um valor secundário; importa que fique inscrita, pelo público recetor da mensagem, a opinião emitida em certa direçãa e com propósito específico, sobre um facto - verdadeiro ou falso -, em detrimento deste. 
ULP Law Review | Revista de Direito da ULP

Vol. 13, n. .1

doi: 10.46294/ulplr13n1 ga3

E aqui se pode divisar uma incongruência e incompatibilidade desde novo cenário, com as classificações acima mencionadas, quando se distinguiu factos de opinião, no contexto do exerć́cio da liberdade de expressão e de imprensa num quadro convencional de comunicação social.

Não nos parece, hoje, concebível que as categorias de responsabilização que podem nortear os meios de comunicação formais (mesmo os de ambiente digital) de possam aplicar correspondentemente ao ambiente mediático digital online - com propagação virtualmente global, irreversível e de impacto e consequências imprevisíveis -, pelo que outros se deverão procurar.

Parece-nos que deverão exautorar-se novas formas de controlo prévio dos conteúdos de informação (digital), bem como a aplicação de mecanismos de fact-checking enquanto modelos de controlo da autenticidade ou verosimilhança da informação divulgada nos ambientes digitais, sob pena de haver uma recondução a modelos (não assumidos) de censura.

Eventualmente, as formas de assegurar, a montante das atividades de comunicação de informação em sítios e plataformas informais, através da atividades das operadoras de serviços electrónicos e digitais, a fiabilidade da identificação da autoria das mesmas, poderiam constituir um princípio procedimental que conduzisse à efetiva responsabilização dos agentes de condutas criminalmente relevantes.

Outra das formas - porventura menos consensual e que suscitaria, concede-se, acrescidas dificuldades - seria a de ampliar as exceções enquadradas pelo $\mathrm{n}^{0}{ }^{2}$ do art. 10. ${ }^{\circ}$ da CEDH.

Perto do final do nosso excurso, cremos continuarem a justificar-se as perguntas: para que serve, afinal, a liberdade de expressão? Porque é que a Constituiçãa - a nossa e muitas outras - fez questão de assegurar esse direito? Seria necessário garanti-lo para proteger as opiniões maioritárias? Ou para permitir o discurso que não causa desconforto a ninguém? Ou para reafirmar opiniões universais e pacíficas? 
ULP Law Review | Revista de Direito da ULP

Vol. 13, n. .1

doi:10.46294/ulplr13n1ga3

Não seriam essas, formas redundantes de assegurar a liberdade de expressão e que, no fundo, fariam pouco sentido?

0 direito à liberdade de expressão serve, precisamente, para proteger a liberdade, nossa e dos outros, de nos expressarmos, mesmo - ou sobretudo - quando essa expressão é incómoda. 0 que importa assegurar é, não a possibilidade do elogio, mas, precisamente, a expressão que desagrada, a opinião que incomoda, o comentário ou a atitude que critica e escandaliza. A liberdade de expressãa servirá para proteger aquilo que nos pode ser hostil, que não apreciamos que os outros digam, façam ou pensem.

Discursos racistas, homofóbicos, machistas, negacionistas, devem poder ser apresentados $^{57} .0$ direito de ter opiniões despropositadas, inconvenientes, insultuosas, sem sentido, deve ser assegurado a todos.

Será deplorável que persistam atitudes reveladoras de certos tipos de mentalidade. Mas não deve caber, a quem não concorda com elas, proibi-las ou reprimi-las: caberá, sim, contrariar os argumentos desses discursos. E para isso, deverá exercitar-se, também, 0 direito à liberdade de expressão.

É assim que deve funcionar 0 jogo da livre expressão e do debate livre e frontal de ideias e convicções, exceptuando-se as situações de discursos de ódio ou de instigação pública à prática de crimes: a perspetiva de cada um, no final de um debate, poderá manter-se. Contudo, em cada debate existe a (pequena) possibilidade de o adversário, ou terceiros, serem persuadidos a reconhecer 0 acerto da nossa posição, ou de alguns dos seus elementos, ou a falta de fundamento em que lavra certo discurso. É por isso que a liberdade de expressão pretende proteger essa possibilidade.

Nos ambientes de discussão - digital ou noutros suportes -, cada agente deve ser responsável (e responsabilizado) pelo que escreve ou pelo que diz e, consequentemente apreciada, pelos outros, a sua posição. Às posições e discursos racistas, homofóbicos, machistas, negacionistas, deve responder-se sempre, com discursos de sinal contrário, que encerrem argumentos, factos e críticas fundamentados. Só através do confronto público e

\footnotetext{
${ }^{57}$ Naturalmente que não se faz aqui a apologia de qualquer desses discursos, antes se pretende evidenciar em termos argumentativos, a pertinência da tutela do direito à expressão dos mesmos.
} 
ULP Law Review | Revista de Direito da ULP

Vol. 13, n. .1

doi:10.46294/ulplr13n1ga3

aberto, dessas formas de expressão com os seus erros de pressupostos, com os seus preconceitos e as suas deficiências lógicas, poderemos combatê-las com alguma expectativa de demonstrar a sua falta de fundamento.

Suprimir esses tipos de discurso - ao proibi-los ou reprimi-los -, não será muito inteligente nem avisado, pois tal será remetê-los para domínios marginais onde escapam ao controlo das opiniões contrárias. Eles continuarão, porém, a corroer os fundamentos da organização democrática do Estado e a afirmar as suas "verdades" sem contestação nem crítica. Esses discursos devem, também por isso, ter direito a um espaço na discussão pública - sob pena de, sendo remetidos para a "clandestinidade", ser muito mais penoso e difícil demonstrar as suas incoerências, as suas falácias e a suas inconsistências lógicas e principiais.

Poderemos, assim, condluir pela total pertinência da manutenção de um quadro atual de ampla garantia da liberdade de expressão, mesmo quando com ela conflituem posições que a ponham em causa. E aqui se convoca o princípio da admissão das diferenç̧as culturais e das differentes representaçōes de muitos fenómenos políicicos e sociais, ñ̃o como uma ameaça, mas antes como uma fonte para a compreensão do complexo enigma antropológico - a pessoa humana, na sua dimensão coletiva ou individual -, competindo à esfera da educcação, numa sociedade plural e multicultural, o papel mais interveniente no processo de indusão e de respeito e tolerância pelas diferenças.

Tolerância não é indiferenç̧, embora os conceitos por vezes se possam, precipitadamente, confundir. A atitude indiferentista rejeita todo o valor prevalente relativamente aos outros, redundando na consequência absurda do respeito pela intolerância.

Esta conceção tem pressuposta a marca do relativismo ${ }^{58} \mathrm{e}$ a dificuldade de assumirmos compromissos estáveis e duradouros, quer a nível pessoal, quer a nível cultural.

\footnotetext{
${ }^{58} 0$ relativismo, segundo GILBERT HARMAN, diz-nos que não existe uma moral verdadeira, mas que existem muitos quadros de moralidade diferentes, nenhum mais correto que os outros («Virtue Ethics without Character Traits», in Byrne Stalnaker e Wedgewood (orgs.), Fact and Value, Cambridge, MA, MIT Press, 2001, pp. 117-127).
} 
ULP Law Review | Revista de Direito da ULP

Vol. 13, n. .9

doi:10.46294/ulplr13n 1 ga3

A tolerância surge, também, como uma atitude cívica na abertura a um diálogo e à compreensão dos valores e ao confronto e denúncia crítica e positiva dos seus limites. Este é 0 único caminho possível para a aceitação da diferença do outro, no respeito pela sua dignidade. Um caminho que conduzirá necessariamente à paz, e que se há-de percorrer em diálogo e compreensão, algo só possível através da educação. 0 pressuposto básico para esta paz é que todas as conceções do mundo, todas as culturas, embora estruturalmente diferentes, estejam unidas pelo princípio da defesa incondicional da pessoa humana e da sua dignidade.

Nesse sentido, tolerância não se confunde com indiferentismo nem com relativismo. É uma atitude que reconhece o significado axiológico de manifestação de expressões culturais diferentes e mesmo antagónicas, respeitando-as, sem abdicar, porém, do denominador matricial da eminente dignidade e autonomia da pessoa humana.

Nessa medida, tolerar uma expressão não significa aceitar o seu conteúdo. Significa, tão só, aceitar, nesses termos, a sua existência ${ }^{59}$, mas poder contrapor-lhe argumentos e ideias contrapostas.

Talvez tenhamos descoberto, afinal, que o mau gosto e as opiniões peregrinas tornam a coexistência, em determinadas circunstâncias, muito difíicil, mas a sua interdição torna-a radicalmente impossível.

A grande questão que definitivamente se coloca é como garantir efetivamente a liberdade de expressão num contexto global de crescentes atentados, violações, desprezo, condicionamento e - porventura mais grave - indiferença.

\footnotetext{
${ }^{59} 0$ paradoxo popperiano da (in)tolerância é aqui ilustrativo por nos ajudar a entender o significado da tolerância face à intolerância: apenas se deve admitir a expressão de filosofias e opiniōes intolerantes se se Ihes puder contrapor argumentos racionais para as conter face à opinião popular; suprimi-las, seria imprudente, se houver essa possibilidade. Caso contrário, as atitudes intolerantes não devem ser toleradas, sob pena de colocarem em causa a tolerância. Daí, o paradoxo contraposto pelos intolerantes: «Afinal, se a tolerância é intolerante, porque não podemos nós sê-lo? ?». Para Popper, o termo intolerância não deve traduzir aquelas situações de expressão de ideias "intolerantes" que deixam alguém incomodado ou quando tais ideias parecem indelicadas, iritantes ou desagradáveis. Intolerância - se for essa a palavra certa para descrever a atitude - só deve ser empregada frente a "punhos e armas", ou, eventualmente, algo pior.
} 
ULP Law Review | Revista de Direito da ULP

Vol. 13, n. .1

doi:10.46294/ulplr13n 1 ga3

\section{Considerações condusivas}

0 processo de globalização mediática - que foi, de resto, um dos processos iniciais do fenómeno da Globalização - parece demonstrar que as implicações induzidas pelos novos modelos de comunicação de informação e de opinião ao nível do complexo regulatório da liberdade de expressão, mormente através dos meios tecnológicos digitais, não podem ser mais ignoradas.

Essas implicações traduzem-se, de facto, na alteração dos modos de comunicação e difusão de informação que pouco têm de comum com os quadros de produção de informação ou de opinião de moldes clássicos em que tinham intervenção os meios de comunicação convencionais, nomeadamente ao nível da determinação dos virtuais responsáveis pelos excessos penalmente relevantes da liberdade de expressão.

Os novos cenários de produção e de circulação de informação no ambiente digital potenciam, pois, novas inquietações e perplexidades, colocando em causa as formas tradicionais em que se decantou a fundamentação jurídica para as soluções normativas que importa(va) estabelecer quando esteja em causa um conflito entre a liberdade de expressão e de informação e valores como a honra e o bom nome, a imagem, a palavra, os segredos profissionais, de Estado ou de justiça. Tais alterações analisam-se, ainda, no plano da pulverização dos pólos de responsabilização pela difusãa de informação com contornos ilícitos e, igualmente, no âmbito das dificuldades de produção de prova da autoria e comparticipação e, consequentemente, da responsabilidade.

Ao invés de se assumirem como instrumentos de escrutínio dos poderes públicos, os novos Media digitais (não formais) podem converter-se em veículos de desinformação, propaganda e de condicionamento da opinião da comunidade, ao postergar os valores da objetividade, do contraditório e da ética e deontologia profissional.

Para um tal estado de coisas não se conhecem antídotos seguros, mormente no tocante à equação sempre presente no confronto entre liberdade de expressão e direito à honra e ao bom nome ou outros direitos fundamentais vulnerados. Apenas recomendações, 
ULP Law Review | Revista de Direito da ULP

Vol. 13, n. .1

doi:10.46294/ulplr13n 1 ga3

porventura pouco eficazes no caso, mas que, de qualquer modo, se ousa sugerir: autovigilância e sensibilização dos cidadãos por investimento educacional, bem como uma concesção do processo como instrumento de cidadania, que garanta a proteção de valores fundamentais da convivência comunitária e a dignidade e autonomia da pessoa.

A liberdade de expressão não deve conceber-se como uma concessão do Estado. Este deve apenas regular 0 seu exerćício e limitar 0 seu âmbito enquanto se justificar constitucionalmente a tutela de outros direitos fundamentais, de acordo com 0 estatuído no art. 10. ${ }^{\circ}$,.${ }^{0} 2$ da CEDH.

A liberdade de expressão será sempre um valor paradoxalmente cada vez mais precioso e carente de tutela no contexto da sociedade de informação e mediática, pelo que a sua salvaguarda será sempre mais vantajosa do que a imposição de limitaçōes, devido aos seus putativos inconvenientes. Deve reconhecer-se como valor fundacional e estruturante das sociedades pluralistas e democráticas, com redobrado significado perante ameaças e violações concretizadas em muitas latitudes, 0 que realça 0 insubstituivivel papel que os tribunais devem continuar a protagonizar. 